\title{
Czynnik obywatelski w sądownictwie II Rzeczypospolitej ${ }^{1}$
}

\section{WSTĘP}

Udział czynnika społecznego, współcześnie określanego mianem obywatelskiego, w sądownictwie stanowił i stanowi istotne zagadnienie prawnoustrojowe. Korzeniami swymi sięga starożytności, zarówno bowiem w starożytnej Grecji, jak i Rzymie ludność aktywnie w nim uczestniczyła ${ }^{2}$. Jednak na współczesne europejskie modele udziału społeczeństwa w wymiarze sprawiedliwości wpływ miały rozwiązania, które zostały przyjęte w XVIII i XIX w., w szczególności francuska struktura sądownictwa przyjęta $\mathrm{W}$ epoce napoleońskiej odegrała istotną rolę na obszarze Europy kontynentalnej ${ }^{3}$. Chodzi przede wszystkim o instytucję sędziów

1 Tematyką tą zajmowałem się wcześniej w związku z wygłoszonym referatem pt. Udział obywateli w wymiarze sprawiedliwości II Rzeczypospolitej na ogólnopolskiej konferencji naukowej „Udział obywateli w sprawowaniu wymiaru sprawiedliwości”, zorganizowanej przez Wydział Prawa i Administracji Uniwersytetu Warszawskiego w dniach 6-7 kwietnia 2018 r. Zob. R. Jastrzębski, Udział obywateli w wymiarze sprawiedliwości II Rzeczypospolitej [w:] R. Piotrowski (red.), Udzial obywateli w sprawowaniu wymiaru sprawiedliwości, Warszawa 2021, s. 25-49.

${ }^{2}$ K. Potocki, O początku historyi, korzyściach i niedogodnościach instytucyi sądu przysięglych, rzecz krótka, Warszawa 1819; K. Machczyński, Pogląd historyczny na sądownictwo ludowe jako źródto instytucyi przysięgłych, Warszawa 1869; K. Koranyi, Powszechna historia państwa i prawa, t. I, Warszawa 1965, s. 32, 64-66, 103, 124-127, 155; M. Rybicki, Lawnicy ludowi w sądach PRL, Warszawa 1968, s. 9 i n.

3 Szerzej: E. Waśkowski, Sąd przysięgłych w procesie cywilnym, „Ruch Prawniczy, Ekonomiczny i Socjologiczny” 1930, z. 1; B. Leśnodorski, Czynnik społeczny w sądach na przestrzeni dwu stuleci (XVIII-XX), „Państwo i Prawo” 1966, z. 3; S. Salmonowicz, Lawa przysięglych $w$ dziewiętnastowiecznej Francji: od mitu do jego destrukcji [w:] J. Malec, W. Uruszczak (red.), Ustrój i prawo w przeszłości dalszej i bliższej. Studia historyczne o prawie dedykowane Prof. Stanistawowi Grodziskiemu w pięćdziesiątą rocznicę pracy naukowej, Kraków 2001. 
pokoju oraz sędziów przysięgłych, które funkcjonowały wcześniej w Wielkiej Brytanii oraz Stanach Zjednoczonych. Co interesujące, niektórzy badacze uważali, że sądy przysięgłych zostały przeniesione na obszar Anglii przez Normanów za Wilhelma Zdobywcy w XI w. ${ }^{4} \mathrm{~W}$ okresie Wielkiej Rewolucji Francuskiej instytucje te zostały unormowane przez ustawodawstwo francuskie, a następnie wprowadzone w innych państwach europejskich ${ }^{5}$.

Reformy sądowe w XIX w., odnoszące się do udziału czynnika społecznego w wymiarze sprawiedliwości, objęły państwa zaborcze: Austrię, Niemcy i Rosję ${ }^{6}$. W pierwszym z nich dotyczyło to zmian ustrojowych, które zaszły po $1848 \mathrm{r}$. i były związane m.in. $z$ wprowadzaniem ławy przysięgłych w niektórych sprawach karnych ${ }^{7}$. W drugim reformy sądowe miały miejsce w 1849 i $1877 \mathrm{r}^{8} \mathrm{~W}$ ostatnim z państw, Cesarstwie Rosyjskim, w 1864 r. została przeprowadzona najbardziej

${ }^{4}$ Szerzej: J.J. Bossowski, Czynnik ludowy w sadzie karnym (odbitka z „Ruchu Prawniczego i Ekonomicznego" z 1921 r.), Poznań 1924; M. Szerer, Sądownictwo angielskie, Warszawa 1935; K. Bzowski, Sady przysieglych (odbitka z Encyklopedji Prawa Karnego), Warszawa ok. 1939; K. Koranyi, Powszechna historia państwa i prawa, t. IV, Warszawa 1967, s. 82-83, 97-98, 124-132, 174-175; K. Baran, Powstanie i ewolucja angielskiej ławy przysięgłych (między średniowieczem a XIX stuleciem) [w:] M. Kwiecień, M. Małecki (red.), Szkice z dziejów ustroju i prawa poświęcone pamięci Ireny Malinowskiej-Kwiatkowskiej, Kraków 1997; J. Halberda, Lawa przysięgłych $w$ angielskim procesie cywilnym (XII-XIII wiek) [w:] S. Grodziski, D. Malec, A. Karabowicz, M. Stus (red.), Vetera Novis Augere. Studia i prace dedykowane Profesorowi Wactawowi Uruszczakowi, t. I, Kraków 2010; E. Gmurzyńska, Ewolucja instytucji sędziów pokoju w Stanach Zjednoczonych, „Studia Iuridica Lublinensia” 2019, nr 1.

${ }^{5}$ Szerzej: K. Potocki, Wystawienie ważniejszych części instytucyi Przysięgtych, czytane na sessyi Deputacyi d. 24 września 1818, b.m. 1818; W. Miklaszewski, O znaczeniu sądu przysięgłych, rzecz publicznie w auli Szkoły Głównej Warszawskiej, w dniu 2 kwietnia 1867 r. wyłożona, Warszawa 1867, s. 3 i n.; idem, O stanowisku prezydującego w sądzie przysięglych, Warszawa 1867; A. Bojarski, O sądach przysięgłych z uwzględnieniem projektu nowej ustawy o postępowaniu karnem dla niewęgierskich krajów państwa austryackiego, Kraków 1868; R. Heinze, Angielska jury w porównaniu z francuzko-niemieckim sądem przysięglych, Warszawa 1874; A. Mogilnicki, Sady przysięglych, Warszawa 1899, s. 2-6; S. Glaser, Kompetencja sadów przysięłych, Lublin 1923, s. 11 i n.; S. Wolski, Istota zagadnienia sądów przysięgłych, „Wileński Przegląd Prawniczy” 1935, nr 8; K. Koranyi, Powszechna historia państwa i prawa, t. IV, s. 253-254; B. Leśnodorski, Czynnik społeczny $w$ sadach...; C. Kulesza, Udziat czynnika społecznego $w$ orzekaniu $w$ perspektywie historyczno-prawnoporównawczej, „Białostockie Studia Prawnicze” 2016, z. 21; J. Maziarz, Sądy przysięgłych w II Rzeczypospolitej w praktyce Sądu Okręgowego w Krakowie, Warszawa 2017, s. 73-83.

${ }^{6}$ K. Koranyi, Powszechna historia państwa i prawa, t. IV, s. 288-289; M. Rybicki, Ławnicy ludowi..., s. 39-52.

${ }^{7}$ Szerzej: E. Dubanowicz, W sprawie sądów pokoju na ziemiach polskich (Studjum prawno-historyczne), „Przegląd Prawa i Administracji” 1919, z. 4-6, s. 133 i n.; K. Grzybowski (red.), Historia państwa i prawa Polski, t. IV: Od uwłaszczenia do odrodzenia państwa, pod ogólną red. J. Bardacha, Warszawa 1982, s. 430-432.

${ }^{8}$ K. Grzybowski (red.), Historia państwa i prawa Polski, t. IV, s. 602-603. 
nowoczesna reforma sądowa ${ }^{9}$, która dzieliła strukturę wymiaru sprawiedliwości na sądownictwo pokojowe oraz ogólne, w tym wprowadzała sądy pokoju oraz sądy przysięgłych. W przypadku sądów przysięgłych Aleksander Mogilnicki uznał, że stanowiły one wówczas najlepszy ze znanych rodzajów sądów i powinny rozpatrywać tylko sprawy kryminalne, z wyłączeniem wykroczeń policyjnych, przy czym „sąd przysięgłych w tej formie, w jakiej istnieje w Rosyi, w zasadzie odpowiada wymaganiom teoryi" 10 .

Co istotne, reforma sądowa w Rosji nie została w całości wprowadzona na obszarze Królestwa Polskiego w 1876 r., dotyczyło to zwłaszcza sądów przysięgłych. W 1923 r. Mogilnicki stwierdził:

Względy polityczne, a po części językowe stanęły temu na przeszkodzie. Rząd rosyjski nie chciał wprowadzić sądów z językiem urzędowym polskim, a zdawał sobie sprawę z niemożliwości tworzenia ławy przysięgłych, jeżeli językiem sądowym pozostanie rosyjski. Tak samo zresztą rząd rosyjski nie wprowadzał sądów przysięgłych $w$ innych ziemiach podbitych o ludności nierosyjskiej: w krajach nadbałtyckich, na Kaukazie ${ }^{11}$.

Na obszarze Królestwa Polskiego natomiast zostało utworzone sądownictwo pokojowe, które składało się z sądów wiejskich (gminnych) oraz sądów pokoju. Pierwsze z nich były ustanowione dla wsi, czyli 1-3 gmin administracyjnych, i miały charakter kolegialny. Sędziów gminnych i ławników wybierały zgromadzenia gminne, przy czym kandydaci na te stanowiska powinni byli zostać zatwierdzeni przez ówczesne władze. Sądy pokoju zostały utworzone dla miast i były jednoosobowe. W praktyce funkcję sędziego pokoju sprawował urzędnik państwowy. Sądem odwoławczym (apelacyjnym) zarówno od orzeczeń sądów gminnych, jak i sądów pokoju był zjazd sędziów pokoju ${ }^{12}$.

${ }^{9}$ Szerzej: S. Glaser, Kompetencja sądów przysięgtych, s. 34-36; K. Koranyi, Powszechna historia państwa i prawa, t. IV, s. 302-303; D. Sołodow, Sąd przysięgłych w Rosji. Tradycja historyczna istan wspótczesny [w:] W. Cieślak, S. Steinborn (red.), Profesor Marian Cieślak-osoba, dzieło, kontynuacje, Warszawa 2013; M. Materniak-Pawłowska, Z dziejów sądów przysięgłych na ziemiach polskich w XIX wieku, „Czasopismo Prawno-Historyczne” 2014, t. LXVI, z. 1.

${ }^{10}$ A. Mogilnicki, Sady przysięgłych, Warszawa 1899, s. 97.

11 A. Mogilnicki, Sądy przysięgłych w Polsce, „Gazeta Administracji i Policji Państwowej” 1923, nr 25, s. 397. Por. M. Materniak-Pawłowska, Sady przysięglych na ziemiach polskich [w:] T. Maciejewski, W. Zalewski (red.), Kara kryminalna. Perspektywa historyczna i penologiczna, Gdańsk 2019.

12 Szerzej: E. Dubanowicz, W sprawie sądów pokoju..., s. 127 i n.; A. Korobowicz, Reforma ustroju sądownictwa w Królestwie Polskim po 1863 r. Przygotowania i treść, Lublin 1976; idem, Sąownictwo Królestwa Polskiego 1876-1915, Lublin 1995; K. Grzybowski (red.), Historia państwa i prawa Polski, t. IV, s. 213-218; A. Bereza, Sadownictwo pokojowe w guberni lubelskiej na tle Królestwa Polskiego (1876-1915), Lublin 2004; A. Mogilnicki, Wspomnienia adwokata i sędziego, Warszawa 2016, s. 108 i n. 
Warto zaznaczyć, że sądownictwo pokojowe wprowadzone przez rosyjskiego zaborcę było oceniane pozytywnie. Zwrócił na to uwagę w 1919 r. Edward Dubanowicz, który stwierdził:

[...] sądy pokoju w Królestwie Polskiem wywiązały się najzupełniej z włożonego na nie zadania [bowiem] Przyczyniły się wiele do podniesienia moralności, zmysłu społecznego, poczucia prawnego, pośrednio i dobrobytu ludności. Sprawowane przez ludzi miejscowych, zazwyczaj wykształconych, równocześnie zaś obznajomionych ze stosunkami miejscowemi a zwłaszcza ze szczególniejszemi potrzebami ludności wiejskiej, oddanej rolnictwu, zdobyły one wkrótce, nawet mimo zaprowadzenia w nich obcego, rosyjskiego języka, zaufanie ogółu. [...] Nic dziwnego tedy, że przetrwawszy w Królestwie Polskiem do chwili bieżącej, muszą być i sądy pokoju brane w rachubę jako pierwsze ogniwo w przyszłem, zreformowanem sądownictwie polskiem ${ }^{13}$.

Uzasadniał to przede wszystkim tym, iż

Obserwacja działania sądów pokoju okazuje, w pierwszych zwłaszcza latach po ich wprowadzeniu w życie, dwojaki skutek: znaczne obniżenie ilości spraw spornych, powtóre zaś wysoką liczbę sporów zakończonych pojednaniem stron ${ }^{14}$.

Wszystkie wymienione wyżej reformy należy sprowadzić do wspólnego mianownika, którym było dopuszczenie ludności do uczestniczenia w sądownictwie. Zasadniczo sąd może mieć charakter: zawodowy, niezawodowy oraz mieszany. Dwa ostatnie przypadki są związane z zakresem udziału czynnika społecznego w sprawowaniu wymiaru sprawiedliwości. Sąd niezawodowy, w którym uczestniczy tylko czynnik społeczny (obywatelski), dotyczył przede wszystkim obsady sądów niższych instancji zarówno w sprawach cywilnych, jak i karnych, np. w postaci sądów pokoju czy sądów gminnych (wiejskich). W ich kognicji były zwykle sprawy o małej wartości przedmiotu sporu bądź zagrożone niską sankcją karną. Typ mieszany był związany z dopuszczeniem do udziału w składzie sądowym przedstawicieli ludności w postaci np. ławników, sędziów handlowych ${ }^{15}$. Łączy się z tym systemem ława przysięgłych (sędziowie przysięgli), która orzekała w określonych sprawach karnych o winie podsądnego. Wymiar kary zaś należał do sędziów zawodowych. Uważano, że sądy przysięgłych miały m.in. dać podsądnemu rękojmię bezstronności, wzbudzić zaufanie społeczeństwa do wymiaru sprawiedliwości, neutralizować wpływ władzy państwowej na sądownictwo, zmniejszyć liczbę przestępstw ${ }^{16}$. Ponadto sądy przysięgłych, jak stwierdzono jeszcze przed wybuchem I wojny

13 E. Dubanowicz, W sprawie sądów pokoju..., s. 132-133.

14 Ibidem, s. 151.

15 J.J. Bossowski, Czynnik ludowy..., s. 17 i n.

16 Szerzej: W. Miklaszewski, O znaczeniu sądu przysięgłych..., s. 35-37; A. Mogilnicki, Sądy przysiegtych, Warszawa 1899, s. 7 i n. 
światowej, były „zaprowadzone na kontynencie w czasach wielkich wstrząśnień politycznych i społecznych, spowodowanych wielką rewolucyą francuską" oraz „wchodziły w program ówczesnych postulatów politycznych i stanowić miały paladyum wolności osobistej przeciw wszelkim zamachom władzy państwowej, a zarazem służyć do realizowania celów politycznych"17.

\section{USTAWY ZASADNICZE II RZECZYPOSPOLITEJ}

Odzyskanie przez państwo polskie niepodległości po I wojnie światowej postawiło przed młodą Rzeczpospolitą Polską nowe wyzwania prawne, które dotyczyły, poza kodyfikacją oraz unifikacją prawa, organizacji wymiaru sprawiedliwości. Warto przy tym zaznaczyć, że kształtowanie się granic nowo powstałego państwa polskiego, co miało wpływ na zakres terytorialny właściwości sądów polskich, formalnie trwało aż do 1923 r., czyli uznania granic wschodnich państwa polskiego przez Konferencję Ambasadorów ${ }^{18}$. Dlatego ówczesna organizacja wymiaru sprawiedliwości została oparta na istniejącym status quo, czyli rozwiązaniach państw zaborczych, które były zmieniane oraz uzupełniane stopniowo przez polskie regulacje prawne. W praktyce zaś do wejścia w życie rozporządzenia Prezydenta Rzeczypospolitej z dnia 6 lutego 1928 r. Prawo o ustroju sądów powszechnych ${ }^{19}$, czyli przez około 10 lat, sądownictwo powszechne regulowały zasadniczo rozwiązania prawne pochodzące z okresu sprzed wybuchu I wojny światowej. Oczywiście był z tym związany udział obywateli ówczesnego państwa polskiego w wymiarze sprawiedliwości, który w dużym stopniu zależał od prawa obowiązującego w poszczególnych dzielnicach pozaborowych.

Należy zaznaczyć, że ogólne zasady wymiaru sprawiedliwości, w tym udziału w nim obywateli, regulowały dwie ustawy zasadnicze, czyli ustawa z dnia 17 marca 1921 r. Konstytucja Rzeczypospolitej Polskiej ${ }^{20}$ oraz ustawa konstytucyjna z dnia 23 kwietnia $1935 \mathrm{r}^{21}$ Podstawowe założenia pierwszej z wymienionych konstytucji, $\mathrm{w}$ tym w zakresie wymiaru sprawiedliwości, formalnie obowiązywały na podstawie Manifestu Polskiego Komitetu Wyzwolenia Narodowego (PKWN) z dnia 22 lipca

17 P. Stebelski, Sądy przysięgtych i sądy ławnicze [w:] Księga Pamiątkowa ku uczczeniu 250-tej rocznicy założenia Uniwersytetu Lwowskiego przez króla Jana Kazimierza r. 1661, t. II, Lwów 1912, s. 7.

${ }^{18}$ Oświadczenie rządowe z dnia 20 kwietnia 1923 r. w przedmiocie uznania granic wschodnich Rzeczypospolitej, Dz. U. Nr 49, poz. 333. Zob. C. Berezowski, Odrodzenie państwa polskiego $w$ świetle prawa międzynarodowego. Granice państwa i obywatelstwo [w:] F. Ryszka (red.), Historia państwa i prawa Polski 1918-1939, cz. I, pod ogólną red. J. Bardacha, Warszawa 1962, s. 53-63.

19 Dz. U. Nr 12, poz. 93.

${ }^{20}$ Dz. U. Nr 44, poz. 267.

${ }^{21}$ Dz. U. Nr 30, poz. 227. 
$1944 \mathrm{r}^{22}$, także po zakończeniu II wojny światowej ${ }^{23}$. Oczywiście w II Rzeczypospolitej, a zwłaszcza po 1944 r., udział obywateli w wymiarze sprawiedliwości, na podstawie ustawy zasadniczej z $1921 \mathrm{r}$., nie był w pełni realizowany w praktyce.

Konstytucja z 17 marca 1921 r. poświęciła wymiarowi sprawiedliwości rozdział IV pt. Sądownictwo (art. 74-86 Konstytucji), w tym regulowała organizację trzech trybunałów oraz sądów administracyjnych. Do trybunałów należało zaliczyć Trybunał Stanu, Trybunał Kompetencyjny oraz Najwyższy Trybunał Administracyjny. W skład pierwszego z nich, zgodnie z art. 64 Konstytucji, wchodził I Prezes Sądu Najwyższego - przewodniczący, oraz 12 członków, w tym ośmiu wybieranych przez Sejm oraz czterech przez Senat, spoza ich grona. Członkami Trybunału były osoby niepiastujące żadnego urzędu państwowego i korzystające z pełni praw obywatelskich ${ }^{24}$.

Trybunał Kompetencyjny - zgodnie z art. 86 Konstytucji z 1921 r. - został powołany do rozstrzygania sporów o właściwość między władzami administracyjnymi a sądami. Działalność oraz organizację Trybunału normowała ustawa z dnia 25 listopada 1925 r. o Trybunale Kompetencyjnym ${ }^{25}$, która obowiązywała bez zmian przez cały okres II Rzeczypospolitej. Trybunał składał się z trzech grup członków: sędziów Sądu Najwyższego, sędziów Najwyższego Trybunału Administracyjnego (NTA) oraz grupy profesorskiej. W skład tej ostatniej wchodziło sześć osób odznaczających się szczególną znajomością prawa, które nie piastowały żadnego urzędu w sądownictwie czy administracji. Po trzech kandydatów do niej przedstawiały wydziały prawa uniwersytetów państwowych ${ }^{26}$.

Pozycję ustrojową NTA regulował art. 73 Konstytucji, zgodnie z którym:

Do orzekania o legalności aktów administracyjnych w zakresie administracji tak rządowej, jak i samorządowej powoła osobna ustawa sądownictwo administracyjne, oparte w swej organizacji na współdziałaniu czynnika obywatelskiego i sędziowskiego z Najwyższym Trybunałem Administracyjnym na czele ${ }^{27}$.

${ }^{22}$ Załącznik do Dz. U. Nr 1, s. 1.

${ }^{23}$ Szerzej: K. Działocha, J. Trzciński, Zagadnienie obowiązywania Konstytucji Marcowej w Polsce Ludowej 1944-1952, Wrocław - Warszawa - Kraków - Gdańsk 1977; K. Działocha, Rola Konstytucji marcowej w prawie państwowym Polski Ludowej, „Acta Universitatis Wratislaviensis”, 1976, t. VII; J. Trzciński, Instytucje ustrojowe okresu przejściowego 1944-1947 [w:] M. Kallas (red.), Konstytucje Polski. Studia monograficzne z dziejów polskiego konstytucjonalizmu, t. 2, Warszawa 1990, s. 248 i n.; M. Wiącek, Znaczenie stosowania Konstytucji Marcowej w Polsce Ludowej dla orzecznictwa sadów i Trybunalu Konstytucyjnego III RP, Warszawa 2012, s. 101 i n.

${ }^{24}$ Ustawa z dnia 27 kwietnia 1923 r. o Trybunale Stanu, Dz. U. Nr 59, poz. 415. Szerzej: W. Komarnicki, Polskie prawo polityczne (geneza i system), Warszawa 1922 (reprint: 2008), s. 285 286, 351-353; M. Pietrzak, Odpowiedzialność konstytucyjna w Polsce, Warszawa 1992, s. 55 i n.

${ }^{25}$ Dz. U. Nr 126, poz. 897.

${ }^{26}$ Szerzej: R. Jastrzębski, Trybunat Kompetencyjny. Kolegium Kompetencyjne. Geneza. Dziatalność. Współczesność, Warszawa 2014, s. 84 i n.

${ }^{27}$ W. Komarnicki, Polskie prawo polityczne..., s. 394-395. 
Organizację i działalność NTA regulowały w II Rzeczypospolitej ustawa z dnia 3 sierpnia 1922 r. o Najwyższym Trybunale Administracyjnym ${ }^{28}$ oraz rozporządzenie Prezydenta Rzeczypospolitej z dnia 27 października 1932 r. o Najwyższym Trybunale Administracyjnym ${ }^{29}$. W praktyce skład NTA miał charakter zawodowy ${ }^{30}$, gdyż nigdy nie doszło do powołania sądów administracyjnych niższej instancji, a co za tym idzie - udziału czynnika obywatelskiego, mimo że były zgłaszane postulaty jego powołania ${ }^{31}$. Wyjątek stanowił obszar dawnego zaboru pruskiego, tzn. województwo poznańskie i pomorskie, oraz górnośląska część województwa śląskiego, na którym istniały: w pierwszej instancji wydziały powiatowe, a w drugiej instancji wojewódzkie sądy administracyjne z siedzibą w Poznaniu, Toruniu i Katowicach. Skład ich pokrywał się w zasadzie ze składem personalnym organów wykonawczych samorządu, tj. wydziałów powiatowych i wojewódzkich ${ }^{32}$.

W rozdziale IV Konstytucji udział obywateli w wymiarze sprawiedliwości został określony w art. 76 oraz 83. Zgodnie z pierwszym z przepisów: „Sędziów mianuje Prezydent Rzeczypospolitej, o ile ustawa nie zawiera innego postanowienia, jednakże sędziowie pokoju z reguły wybierani są przez ludność”. Drugi artykuł stanowił zaś: „Do orzekania o zbrodniach, zagrożonych cięższemi karami, i o przestępstwach politycznych będą powołane sądy przysięgłych. Czyny podlegające sądom przysięgłych, organizację tych sądów i tok postępowania - określą szczegółowe ustawy". W ten sposób udział obywateli w wymiarze sprawiedliwości, jeśli chodzi o sądy powszechne, dotyczył instytucji sędziów pokoju oraz sądów przysięgłych. Organizacja, zakres i sposób działania wszelkich sądów, zgodnie $z$ art. 75 Konstytucji, miał zostać określony w drodze ustawodawczej ${ }^{33}$.

Konstytucja z 23 kwietnia 1935 r. określiła zasady działalności sądownictwa w rozdziale IX pt. Wymiar sprawiedliwości (art. 64-71), w którym został określony także status prawny Trybunału Stanu, Trybunału Kompetencyjnego oraz NTA. W przypadku pierwszego z trybunałów sędziów do niego powoływał Pre-

${ }^{28}$ Dz. U. Nr 67, poz. 600.

29 Dz. U. Nr 94, poz. 806.

${ }^{30}$ Szerzej: D. Malec, Najwyższy Trybunat Administracyjny 1922-1939 w świetle własnego orzecznictwa, Warszawa - Kraków 1999, s. 38 i n.

${ }^{31}$ Szerzej: Ankieta o Konstytucji z 17 marca 1921 r., wyd. W.L. Jaworski, Warszawa 2014 (reprint z 1924 r.), s. 235 i n.; D. Malec, Najwyższy Trybunat Administracyjny..., s. 33-35.

32 Szerzej: R. Klimowiecki, Sądownictwo administracyjne. Najwyższy Trybunat Administracyj$n y$ [w:] F. Ryszka (red.), Historia państwa i prawa Polski 1918-1939, cz. I, s. 262-264; W. Maisel, Wojewódzkie sądy administracyjne w Drugiej Rzeczypospolitej, Warszawa - Poznań 1976, s. 55-76.

${ }_{33}$ Szerzej: W. Komarnicki, Polskie prawo polityczne..., s. 506-514; S. Glaser, Kompetencja sqdów przysięgłych, s. 40-44; Ankieta o Konstytucji..., s. 317-318, 334-345; S. Gołąb, I. Rosenblüth, Ustrój sąów powszechnych, Warszawa 1929, s. 13-14; P. Stachańczyk, Sąd przysięgłych w ustawodawstwie karnym i doktrynie w Polsce w latach 1918-1929, „Czasopismo Prawno-Historyczne” 1989, t. XLI, z. 1, s. 119-121; M. Materniak-Pawłowska, Ustrój sądownictwa powszechnego w II Rzeczypospolitej, Poznań 2003, s. 57-63; J. Maziarz, Sądy przysięgłych..., s. 87-91. 
zydent Rzeczypospolitej spośród sędziów sądów powszechnych, przedstawionych w podwójnej liczbie w połowie przez Sejm, a w połowie przez Senat, przy czym wyjątkiem był przewodniczący - I Prezes Sądu Najwyższego. Warto zaznaczyć, że zgodnie z art. 13 ust. 2 lit. e do prerogatyw Prezydenta Rzeczypospolitej należało powoływanie sędziów Trybunału Stanu ${ }^{34}$. Kolejne dwa trybunały zostały unormowane w art. 70 ust. 1 lit. b i c Konstytucji. Zgodnie z treścią przepisu NTA został powołany do orzekania o legalności aktów administracyjnych, Trybunał Kompetencyjny zaś do rozstrzygania sporów o właściwość między sądami a innymi organami władzy. W ten sposób w ogóle nie został, jeśli chodzi o NTA, uwzględniony czynnik obywatelski na poziomie ustawy zasadniczej. W przypadku zaś Trybunału Kompetencyjnego stan prawny nie uległ większym zmianom, nadal bowiem obowiązywała ustawa z dnia 25 listopada 1925 r. o Trybunale Kompetencyjnym $^{35}$. Co istotne, w Konstytucji z 23 kwietnia 1935 r. nie było w ogóle regulacji dotyczących udziału obywateli w sądownictwie powszechnym, w postaci sądów pokoju czy sądów przysięgłych ${ }^{36}$.

\section{SĄDOWNICTWO POWSZECHNE I SZCZEGÓLNE Z UDZIAŁEM CZYNNIKA OBYWATELSKIEGO}

\section{Okres przed unifikacją}

Wycofanie się z Królestwa Polskiego (Kongresowego) wojsk rosyjskich w 1915 r. spowodowało, że na obszarze tym zostały zorganizowane tzw. sądy obywatelskie, które zlikwidowały władze okupacyjne jesienią tego roku ${ }^{37}$. Następnie, w związku ze zmianą polityki państw centralnych, z dniem 1 września $1917 \mathrm{r}$. rozpoczęły działalność tzw. sądy królewsko-polskie, które orzekały w imieniu Korony Polskiej. W skład ich wchodziły sądy pokoju jako sądy najniższego szczebla ${ }^{38}$.

${ }^{34}$ Ustawa z dnia 14 lipca 1936 r. o Trybunale Stanu, Dz. U. Nr 56, poz. 403.

${ }_{35}$ R. Jastrzębski, Trybunat Kompetencyjny..., s. 56-63.

36 Szerzej: W. Komarnicki, Ustrój państwowy Polski wspótczesnej. Geneza i system, Wilno 1937, s. 341-350; K. Grzybowski, Wymiar sprawiedliwości w świetle przepisów Konstytucji Kwietniowej, „Głos Sądownictwa” 1939, nr 3.

37 Szerzej: E.S. Rappaport, Sądy obywatelskie w Warszawie (Karta z dziejów przełomu sierpniowego r. 1915), Warszawa 1915; J. Bardach, Przemiany ustrojowo-polityczne w latach I wojny światowej [w:] K. Grzybowski (red.), Historia państwa i prawa Polski, t. IV, s. 654-655; S. Płaza, Historia prawa w Polsce na tle porównawczym, cz. 3: Okres międzywojenny, Kraków 2001, s. 618619; A. Korobowicz, Sądownictwo lubelskie u zarania niepodległości (1917-1919), „Rzeszowskie Studia Prawnicze" 2011, nr 1.

38 Przepisy tymczasowe o urządzeniu sądownictwa w Królestwie Polskim, Dz. Urz. Departamentu Sprawiedliwości Tymczasowej Rady Stanu Królestwa Polskiego, Nr 1, poz. 1; Przepisy tymczasowe o dyzlokacji sądów Królewsko-Polskich, Dz. Urz. Departamentu Sprawiedliwości Tymczasowej Rady Stanu Królestwa Polskiego, Nr 1, poz. 2; Ustawy karne tymczasowo obowia- 
Od jesieni 1918 r. następowało zaś stopniowe przejmowanie sądownictwa powszechnego przez władze polskie na poszczególnych obszarach nowo powstałego państwa, które musiało uwzględniać istniejące tam rozwiązania wprowadzone przez państwa zaborcze.

Dawny zabór rosyjski składał się z dwóch obszarów: terenu dawnego Królestwa Polskiego, na który rozciągnięto w $1876 \mathrm{r}$. ze zmianami rosyjskie ustawy sądowe z 1864 r., oraz tzw. Ziemi Wschodnich, na których obowiązywały one od lat 60 . XIX w. W przypadku pierwszego obszaru udział czynnika obywatelskiego dotyczył przede wszystkim sądów pokoju, które składały się z sędziego lub sędziów pokoju i ławników. Wyrokowały one w sprawach cywilnych ${ }^{39} \mathrm{i}$ karnych w kompletach złożonych z sędziego pokoju (przewodniczącego) oraz dwóch ławników. W miastach powiatowych oraz powyżej 10 tys. mieszkańców orzekał tylko sędzia pokoju bez udziału ławników. Sędzia pokoju nie musiał posiadać wykształcenia prawniczego, ale odpowiednią praktykę sądową lub adwokacką, chyba że orzekał jednoosobowo. Ławników w sądach pokoju zasadniczo powoływał prezes sądu okręgowego z listy ułożonej przez zgromadzenia gminne i rady miejskie. Do wymagań, które powinni spełniać kandydaci na ławników, należało zaliczyć posiadanie: obywatelstwa polskiego, nieposzlakowanej opinii, pełni praw oraz dostateczną znajomość języka polskiego. Sędziowie pokoju sprawowali urząd honorowo przez okres 3 lat, nie pobierali przy tym wynagrodzenia, poza odszkodowaniem za czas związany z wykonywaniem swoich obowiązków oraz zwrotem poniesionych kosztów. Udział ławników w sądach pokoju zniosło rozporządzenie Prezydenta Rzeczypospolitej z dnia 19 grudnia 1927 r. zmieniające niektóre przepisy o urządzeniu sądownictwa i o postępowaniu karnem w okręgach sądów apelacyjnych: w Warszawie, Lublinie i Wilnie ${ }^{40}$, a od jego wejścia w życie skład sądów pokoju był jednoosobowy.

zujące na obszarze b. zaboru rosyjskiego, t. II: Ustawa postepowania karnego z ustawami dodatkowemi wydanemi do dnia 1 września 1922 skorowidzem i tezami z orzeczeń Sądu Najwyższego R.P., oprac. A. Mogilnicki, E.S. Rappaport, Warszawa 1923, s. 630-636; S. Gołąb, Organizacja sądów powszechnych, Kraków 1938, s. 45-50; M. Rybicki, Ławnicy ludowi..., s. 52-69; M. Materniak-Pawłowska, Ustrój sądownictwa powszechnego..., s. 17 i n.; R. Jastrzębski, 100-lecie Sądu Najwyższego - geneza, organizacja, działalność [w:] Sąd Najwyższy Rzeczypospolitej Polskiej. Historia i wspótczesność 2007-2017. Suplement do Księgi Jubileuszowej 90-lecia Sądu Najwyższego 1917-2007, Warszawa 2017, rozdz. X, s. 117-156.

${ }^{39}$ Ustawa z dnia 14 lipca 1920 r. o rozszerzeniu właściwości sądów pokoju w sprawach cywilnych, Dz. U. Nr 63, poz. 412. Szerzej: S. Goldsztein, Właściwość sądów pokoju w świetle ustawy z dnia 14 lipca 1920 r. (Dz. Ust. Nr 63, poz. 412), „Gazeta Sądowa Warszawska” 1920, nr 38, 39; P. Jędruszek, O kompetencję sądów pokoju i opłaty od wezwań, „Gazeta Sądowa Warszawska” 1925, nr 9; A. Bardzki, Zakres władzy sędziego pokoju, jako powołanego do zwołania rady familijnej, „Palestra" 1928, nr 3; K. Czernicki, Działalność sądów powszechnych w latach 1925-1928, Warszawa 1931, s. 4; S. Włodyka, Organizacja wymiaru sprawiedliwości [w:] F. Ryszka (red.), Historia państwa i prawa Polski 1918-1939, cz. II, pod ogólną red. J. Bardacha, Warszawa 1968, s. 16-18, 28-29.

${ }^{40}$ Dz. U. Nr 114, poz. 971. S. Kuzior, Instytucja ławników w sądach pokoju b. Królestwa Polskiego, „Gazeta Sądowa Warszawska” 1925, nr 51. 
Ponadto w sądach okręgowych, na podstawie przepisów tymczasowych o urządzeniu sądownictwa w Królestwie Polskim z 1917 r., w sprawach karnych orzekał sędzia zawodowy (przewodniczący) oraz dwóch ławników, a w sprawach handlowych - sędzia zawodowy (przewodniczący) oraz dwóch ławników, wybieranych przez kupiectwo ${ }^{41}$. Na podstawie ustawy z dnia 18 marca $1921 \mathrm{r}$. w przedmiocie niektórych zmian w przepisach tymczasowych o urządzeniu sądownictwa w b. Królestwie Polskiem ${ }^{42}$ ustawodawca zrezygnował ze składu ławniczego w sprawach karnych, pozostawiając skład ławniczy w sprawach handlowych. Minister Sprawiedliwości określał, w jakich sądach działają komplety w sprawach handlowych. Ławnicy handlowi, określani mianem sędziów handlowych, byli wybierani przez kupiectwo, przy czym powinni byli spełniać warunki przewidziane dla ławników, w tym posiadać wykształcenie minimum średnie oraz znać praktykę obrotu handlowego i zwyczaje handlowe ${ }^{43}$.

Działalność sądów na obszarze tzw. Ziem Wschodnich, czyli województw: wołyńskiego, poleskiego, nowogródzkiego i wileńskiego, była związana z prowadzonymi działaniami wojennymi na tym terenie i wydawanymi dla niego regulacjami prawnymi przez władze polskie ${ }^{44}$. W praktyce działalność sądów powszechnych została oparta per analogiam na unormowaniach obowiązujących w okręgu Sądu Apelacyjnego w Warszawie. Istotne znaczenie miało rozporządzenie Komisarza Generalnego Ziem Wschodnich z dnia 15 maja 1919 r. o urządzeniu ogólnego sądownictwa na obszarach wschodnich, podlegających Komisarzowi Generalnemu Ziem Wschodnich ${ }^{45}$, na podstawie którego zostały powołane m.in. sądy pokoju. Ponadto działalność sądów pokoju regulowało rozporządzenie Komisarza Generalnego Ziem Wschodnich w przedmiocie prawa cywilnego i postępowania cywilnego na obszarach wschodnich, podlegających Komisarzowi Generalnemu Ziem Wschodnich ${ }^{46}$. Na jego podstawie sędziowie pokoju orzekali jednoosobowo, a w ich kognicji były sprawy: cywilne o niewielkiej wartości przedmiotu sporu, o przywrócenie zakłóconego lub utraconego posiadania, sprawy o zakłócenie prawa używania serwitutu; w przypadku dwóch ostatnich spraw o ile zdarzenie miało

${ }^{41}$ Szerzej: K. Czernicki, Działalność sądów powszechnych..., s. 11; M. Materniak-Pawłowska, Sadownictwo w sprawach handlowych [w:] R. Jastrzębski (red.), Prawo handlowe i gospodarcze II Rzeczypospolitej, Warszawa 2019, s. 609-613.

${ }^{42}$ Dz. U. Nr 30, poz. 172.

${ }^{43}$ Szerzej: S. Gołąb, I. Rosenblüth, Ustrój sądów powszechnych, s. 38-40; S. Włodyka, Organizacja wymiaru sprawiedliwości, s. 16-17; S. Płaza, Historia prawa w Polsce..., s. 619-621; M. Materniak-Pawłowska, Ustrój sądownictwa powszechnego..., s. 76-78.

${ }^{44}$ M. Materniak-Pawłowska, Ustrój sądownictwa powszechnego..., s. 22-26.

${ }^{45}$ Dz. Urz. Zarządu Cywilnego Ziem Wschodnich Nr 4, poz. 22. Zob. Ustawy karne tymczasowo obowiazujace na ziemiach b. zaboru rosyjskiego, t. II: Ustawa postepowania karnego z ustawami dodatkowemi wydanemi do dnia 30 kwietnia 1921 i skorowidzem, oprac. A. Mogilnicki, E.S. Rappaport, Warszawa 1921, s. 248-253.

46 Dz. Urz. Zarządu Cywilnego Ziem Wschodnich Nr 4, poz. 23. 
miejsce po 1 sierpnia 1914 r. Poza tym do kompletu sądu okręgowego mógł zostać powołany sędzia pokoju lub tzw. sędzia honorowy. Ten ostatni był wyznaczany spośród osób przedstawionych na to stanowisko przez Komisarza Generalnego z listy określonej przez właściwy sąd okręgowy. Następnie, na podstawie rozkazu Naczelnego Wodza W.P. z dnia 15 października 1920 r. w przedmiocie organizacji wymiaru sprawiedliwości na terenach przyfrontowych i etapowych ${ }^{47}$, została powołana struktura, w której także były przewidziane jednoosobowe sądy pokoju oraz sędziowie honorowi. Sytuacja ustabilizowała się po podpisaniu traktatu w Rydze w 1921 r. oraz włączeniu w skład ówczesnego państwa polskiego tzw. Litwy Środkowej ${ }^{48}$.

Działalność i organizacja sądownictwa powszechnego na obszarze dawnego zaboru austriackiego, a zwłaszcza Galicji Wschodniej, były związane z prowadzonymi działaniami wojennymi. Ustrój sądów zasadniczo regulowały unormowania austriackie w dużej mierze pochodzące jeszcze z XIX w., które były stopniowo modyfikowane przez władze polskie. Istotne znaczenie miał w szczególności dekret Naczelnika Państwa z dnia 8 lutego 1919 r. w przedmiocie zmian w urządzeniach wymiaru sprawiedliwości w b. zaborze austrjackim ${ }^{49}$.

Czynnik społeczny był reprezentowany w kilku sądach. W pierwszej kolejności należy wymienić sądy przemysłowe, które znajdowały się w Krakowie, Lwowie i Bielsku. Rozstrzygały one spory wynikające ze stosunku pracy. W ich składzie byli: sędzia zawodowy (przewodniczący) oraz ławnicy, wybierani oddzielnie w równej liczbie przez pracodawców i pracowników. Poza tym w sądach okręgowych działał tzw. senat handlowy, w którego składzie był jeden sędzia niezawodowy, wyznaczany na wniosek izby przemysłowo-handlowej ${ }^{50}$. Największe jednak znaczenie miały funkcjonujące przy sądach okręgowych sądy przysięgłych. Organizację tych sądów normowała austriacka procedura karna z dnia 23 maja 1873 r. Sąd przysięgłych tworzył trybunał, w skład którego wchodzili: przewodniczący i dwóch sędziów sądu okręgowego oraz ława przysięgłych. Przysięgli powinni byli spełniać określone kryteria prawne - mieli to być mężczyźni, którzy ukończyli 30 lat, umiejący pisać i czytać oraz osiągający określony dochód, związany z płaceniem podatku w oznaczonej kwocie. Nie mogli zaś być przysięgłymi: osoby karane sądownie, przeciwko którym toczyło się śledztwo, urzędnicy, wojskowi, nauczyciele szkół

${ }^{47}$ Dz. Urz. Zarządu Terenów Przyfrontowych i Etapowych Nr 2, poz. 9.

${ }^{48}$ Szerzej: S. Gołąb, I. Rosenblüth, Ustrój sądów powszechnych, s. 58-66; P. Stachańczyk, Sąd przysięgłych..., s. 110-111; M. Materniak-Pawłowska, Ustrój sądownictwa powszechnego..., s. 92-102.

49 Dz. Praw Państwa Polskiego Nr 15, poz. 200. Zob. S. Gołąb, Organizacja sądów powszechnych, Kraków 1938, s. 51-54; M. Materniak-Pawłowska, Ustrój sądownictwa powszechnego..., s. $27-37$.

${ }^{50}$ Szerzej: K. Czernicki, Działalność sądów powszechnych..., s. 7; M. Materniak-Pawłowska, Sąownictwo w sprawach handlowych, s. 613-618. 
ludowych, pracownicy poczt, kolei i żeglugi parowej. Pierwotną listę przysięgłych, która była propozycją do publicznego wglądu w celu zgłaszania uwag, sporządzał na podstawie regulacji austriackich naczelnik gminy. Potem przekazywał ją staroście powiatowemu, a w miastach, w których były sądy okręgowe - ich prezesom. Mogli oni żądać sprostowania listy. Następnie z takiej listy komisja, której przewodniczył prezes sądu okręgowego, ustalała listę roczną. $Z$ listy rocznej powoływano losowo członków listy służbowej, która obejmowała przysięgłych na okres jednej kaden-

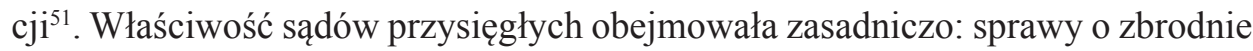
i występki polityczne; sprawy o zbrodnie i występki, popełnione osnową pisma drukowanego; sprawy o zbrodnie pospolite ${ }^{52}$. Warto jednak zaznaczyć, że właściwość rzeczowa sądów przysięgłych w II Rzeczypospolitej była ograniczona m.in. przez sądy doraźne, które przejęły wiele spraw z zakresu ich kognicji ${ }^{53}$.

Na obszarze ziem dawnego zaboru niemieckiego (pruskiego) ustrój sądownictwa regulowało ustawodawstwo niemieckie, przede wszystkim ustawa z dnia 27 stycznia 1877 r. o ustroju sądownictwa, m.in. ze zmianami z 1898 i 1909 r., oraz wydane później regulacje polskie ${ }^{54}$. W strukturze sądownictwa na najniższym szczeblu znajdowały się sądy powiatowe, w skład których wchodził sędzia sądu powiatowego (przewodniczący) oraz dwóch ławników, wybieranych przez specjalne komisje na podstawie spisów osób, przygotowanych w drodze administracyjnej. Ponadto rozporządzenie z dnia 15 grudnia 1919 r. o urządzeniu sądów pokoju w b. dzielnicy pruskiej ${ }^{55}$ ustanawiało sądy pokoju, które były tworzone w miarę potrzeb na obszarze sądu powiatowego. Sądy pokoju składały się z przewodniczącego i dwóch ławników, przy czym przewodniczący nie musiał posiadać kwalifikacji na urząd sędziego. Sędziowie pokoju byli mianowani zasadniczo na okres 3 lat i pełnili swój urząd honorowo ${ }^{56}$.

${ }^{51}$ Szerzej: S. Glaser, Kompetencja sądów przysięgłych, s. 37 i n.; S. Gołąb, I. Rosenblüth, Ustrój sąów powszechnych, s. 68 i n.; K. Grzybowski (red.), Historia państwa i prawa Polski, t. IV, s. 431-433; S. Płaza, Historia prawa w Polsce..., s. 624-625; M. Materniak-Pawłowska, Ustrój sadownictwa powszechnego..., s. 102-122.

${ }^{52}$ Szerzej: J.J. Bossowski, Czynnik ludowy..., s. 13-15; J. Maziarz, Sądy przysięgłych..., s. $104-133$.

53 Szerzej: P. Stachańczyk, Sąd przysięgłych..., s. 112-119; A. Śmiałek, Sąy doraźne w II Rzeczypospolitej, „Czasopismo Prawno-Historyczne” 1984, t. XXXVI, z. 1; K. Winawer, Postepowanie doraźne, Warszawa 1934.

${ }^{54}$ Szerzej: S. Gołąb, I. Rosenblüth, Ustrój sądów powszechnych, s. 81 i n.; S. Gołąb, Organizacja sądów powszechnych, s. 54-63; S. Płaza, Historia prawa w Polsce..., s. 621-624; M. Materniak-Pawłowska, Ustrój sądownictwa powszechnego..., s. 38-46, 122-141.

55 Tygodnik Urzędowy Nr 70, s. 416. Zob. P. Stachańczyk, Sąd przysięglych..., s. 111-112.

56 Szerzej: Sądownictwo na ziemiach b. zaboru pruskiego, „Przegląd Sądowy” 1919, nr 5; B. Cybulski, Wielkopolskie sady pokoju w II Rzeczypospolitej, „Acta Universitatis Wratislaviensis” 1988, No 982, Prawo CLXI. 
W sądach okręgowych działały izby do spraw handlowych, w składzie: sędzia sądu okręgowego (przewodniczący) oraz dwóch sędziów handlowych, którzy byli mianowani na okres 3 lat ze stanu kupieckiego i wykonywali swoje funkcje honorowo ${ }^{57}$. Poza tym w sprawach karnych, które nie podlegały izbom karnym w sądach okręgowych, funkcjonowały sądy przysięgłych ${ }^{58}$. Na podstawie art. 2 rozporządzenia z dnia 15 grudnia 1919 r. o organizacji sądownictwa karnego w b. dzielnicy pruskiej ${ }^{59}$ zawieszono jednak działalność sądów przysięgłych, aż do czasu wypracowania nowych zasad ich organizacji. W związku z tym izby karne rozstrzygały na rozprawie głównej w składzie dwóch sędziów zawodowych i trzech niezawodowych, przy czym w pewnych enumeratywnie wymienionych kategoriach zbrodni (np. morderstwo, zabójstwo, rozmyślne podpalenie, zdrada stanu, zdrada kraju) izby karne orzekały w składzie: dwóch sędziów zawodowych oraz pięciu niezawodowych. Sędziów niezawodowych mianował prezes sądu okręgowego, względnie delegat ministra sprawiedliwości przy sądzie okręgowym, po wysłuchaniu opinii władz administracyjnych. Odmienne regulacje obowiązywały na obszarze województwa śląskiego, które składało się z górnośląskiej części należącej do dawnego zaboru niemieckiego oraz południowej, wchodzącej uprzednio w skład zaboru austriackiego. Na pierwszym obszarze zostały wprowadzone analogiczne rozwiązania jak na pozostałym obszarze dawnego zaboru niemieckiego ${ }^{60}$. Na drugim zaś - na zasadzie ówczesnej praktyki - stosowano rozwiązania przyjęte dla dawnego zaboru austriackiego ${ }^{61}$.

\section{Prace legislacyjne nad ustrojem sądownictwa powszechnego}

Prace dotyczące unifikacji organizacji sądownictwa powszechnego zaczęły się już w 1919 r. i były prowadzone jednocześnie przez Ministerstwo Sprawiedliwości i Komisję Kodyfikacyjną ${ }^{62}$. Zgodnie z zasadami sądownictwa uchwalonymi na Ogólnym Zebraniu Komisji Kodyfikacyjnej w dniach 17-21 maja 1920 r. uznano,

${ }^{57}$ M. Materniak-Pawłowska, Sądownictwo w sprawach handlowych, s. 618-622.

${ }^{58}$ Zob. J.J. Bossowski, Czynnik ludowy..., s. 15-17.

${ }^{59}$ Dz. Urz. Nr 70, s. 414.

${ }^{60}$ Rozporządzenie Ministra Sprawiedliwości z dnia 16 czerwca 1922 r. zaprowadzające zmiany w ustroju sądownictwa w górnośląskiej części Województwa Śląskiego, Dz. U. Nr 46, poz. 390; rozporządzenie Ministra Sprawiedliwości z dnia 13 lipca 1922 r. w przedmiocie utworzenia sądów pokoju w sądach powiatowych w górnośląskiej części Województwa Śląskiego, Dz. U. 52, poz. 485.

${ }^{61}$ Szerzej: B. Cybulski, Sądy powszechne w województwie śląskim w latach 1922-1928, „Acta Universitatis Wratislaviensis" 1992, No 1193, Prawo CXCI; M. Materniak-Pawłowska, Ustrój sq̨downictwa powszechnego..., s. 142-148.

${ }_{62}$ Szerzej: Komisja Kodyfikacyjna Rzeczypospolitej Polskiej. Podkomisja ustroju sadownictwa, t. I, Lwów 1925, s. 3 i n.; S. Gołąb, I. Rosenblüth, Ustrój sądów powszechnych, s. 137 i n.; M. Rybicki, Ławnicy ludowi..., s. 69-82; B. Cybulski, Stosunek Komisji Kodyfikacyjnej RP do laików w sktadach orzekajacych sądów powszechnych (sędziów pokoju, przysięgłych i ławników), 
że „udział czynnika ludowego w sprawowaniu sądownictwa cywilnego nie jest pożądany, z wyjątkiem sądów handlowych", w pierwszej instancji, w których komplet sądowy miał tworzyć sędzia handlowy i dwóch sędziów państwowych. Ponadto drobne sprawy majątkowe miały zostać oddane do rozpoznania sądom gminnym „,Z zastrzeżeniem możności odniesienia się strony przeciw orzeczeniu na drogę prawa" ${ }^{3}$. W przypadku sądów karnych „tworzenie z łona samorządu osobnych sądów gminnych dla rozpoznawania drobnych spraw karnych jest niepożądane", tak jak „udział czynnika ludowego w sądownictwie karnem w postaci sądów ławniczych jest niepożądany”. Wyjątkiem były sądy przysięgłych, które miały rozpoznawać: wszystkie sprawy polityczne oraz przestępstwa zagrożone najcięższymi karami. Co istotne, ostatnia uchwała zapadła większością 19 głosów przeciwko 8, i to wbrew uchwale Wydziału Karnego Komisji Kodyfikacyjnej, który wypowiedział się przeciwko wprowadzeniu sądów przysięgłych. Ponadto sądy przysięgłych nie miały rozpatrywać spraw prasowych, o ile nie należały do wymienionych wyżej dwóch kategorii ${ }^{64}$. Dlatego w uzasadnieniu do pierwszego projektu ustawy o ustroju sądownictwa zwyczajnego, którego referentem był Kamil Stefko, explicite stwierdzono, że „projekt opiera budowę sądu na działalności sędziów o prawniczem wykształceniu akademickiem”, przy czym „,czynnika obywatelskiego projekt nie powołuje do udziału w sądach cywilnych, zaś w ustroju sądownictwa karnego liczy na pomoc społeczeństwa tylko w sądach przysięgłych" ${ }^{65}$.

W tym samym kierunku szedł projekt koreferenta Juliusza Nowotnego, który był w postaci dodatków do wspomnianego projektu K. Stefki. W motywach do niego bowiem uznano, że przy ustalaniu zasad sądownictwa karnego kierowano się wskazaniami, takimi jak: „Wysunięcie na pierwszy plan czynnika sędziego zawodowego, przy jak najdalej idącem ograniczeniu udziału czynnika ludowego, ze względu na stworzenie gwarancyj należytego wymiaru sprawiedliwości”. Dlatego „nie wprowadza projekt ani osobnych sądów gminnych dla rozpoznawania drobnych spraw karnych, ani instytucji urzędów pojednawczych, ani też obieralnych sędziów pokoju, jako czynników wchodzących w skład ustroju sądownictwa zwyczajnego"66.

Późniejsze projekty ustawy o ustroju sądownictwa autorstwa podkomisji oraz projekt Aleksandra Mogilnickiego zawierały jednak postanowienia, które dotyczyły udziału czynnika społecznego w wymiarze sprawiedliwości w postaci: sędziów pokoju, ławników handlowych oraz sądów przysięgłych, w tym sędziów przysięgłych. Projekty te określały m.in. sposób ich wyboru, mianowania na stano-

\footnotetext{
„Acta Universitatis Wratislaviensis” 1992, No 1384, Prawo CCXIII; M. Materniak-Pawłowska, Ustrój sądownictwa powszechnego..., s. 156-176; J. Maziarz, Sądy przysięgłych..., s. 94 i n.

${ }_{63}$ Komisja Kodyfikacyjna..., t. I, s. 9.

${ }^{64}$ Ibidem, s. 11. Zob. S. Gołąb, Organizacja sądów powszechnych, s. 65-68.

${ }^{65}$ Komisja Kodyfikacyjna..., t. I, s. 23.

${ }^{66}$ Ibidem, s. 81.
} 
wisko oraz właściwość ${ }^{67}$. Szczególnie duże zastrzeżenia wzbudziło wprowadzenie sądów przysięgłych, czyli - zdaniem A. Mogilnickiego - dyletantów do wymiaru sprawiedliwości. Dlatego należało je „w miarę możności unieszkodliwić” przez wprowadzenie w skład ławy przysięgłych jak najwięcej inteligencji ${ }^{68}$. Późniejsze posiedzenia podkomisji poświęcone projektowi ustawy dotyczyły m.in. sądów pokoju, w tym zakresu tego pojęcia użytego w Konstytucji z 1921 r., wyboru na stanowisko sędziego pokoju, jego kadencji, wynagrodzenia oraz czynności sądowych; statusu sędziów handlowych; wyboru, kadencji oraz obowiązków sędziów przysięgłych; działalności sądów przysięgłych, ich właściwości ${ }^{69}$.

Następnie ukazał się projekt podkomisji ustroju sądownictwa Komisji Kodyfikacyjnej pt. Ustawa o sadach zwyczajnych, zgodnie z którym udział czynnika obywatelskiego był reprezentowany przez sędziów pokoju, sędziów handlowych oraz przysięgłych ${ }^{70}$. Ostateczny tekst projektu ustawy o sądach powszechnych miał stanowić, zgodnie z jego uzasadnieniem, wstępną pracę, której celem było zaprowadzenie na obszarze całego państwa jednolitego postępowania sądowego w sprawach cywilnych i karnych ${ }^{71}$. Wymiar sprawiedliwości w sprawach cywilnych i karnych nieprzekazanych innym sądom lub władzom miały sprawować, zgodnie z art. 1 projektu, sądy grodzkie, sądy ziemskie, sądy apelacyjne oraz Sąd Najwyższy. Sędziowie pokoju mieli natomiast sprawować wymiar sprawiedliwości w miejscowościach poza siedzibą sądów grodzkich. Zgodnie z kolejnym artykułem

${ }^{67}$ Ibidem, s. 89, 92-93, 102-105, 107-110, 124-125, 131-138, 142, 145-151, 154-155.

68 Vota separata członka Podkomisji ustroju sądownictwa A. Mogilnickiego [w:] ibidem, s. 171.

69 Protokół posiedzenia Podkomisji ustroju sądownictwa z dnia 12 września 1923 r. [w:] Komisja Kodyfikacyjna..., t. I, s. 190-194; protokół posiedzenia Podkomisji ustroju sądownictwa z dnia 15 września 1923 r. [w:] ibidem, s. 257-261; protokół posiedzenia Podkomisji ustroju sądownictwa z dnia 16 września 1923 r. [w:] ibidem, s. 262-270; protokół posiedzenia Podkomisji ustroju sądownictwa z dnia 17 września 1923 r. [w:] ibidem, s. 270-284; protokół posiedzenia Podkomisji ustroju sądownictwa z dnia 20 września 1923 r. [w:] ibidem, s. 323-330; protokół posiedzenia Podkomisji ustroju sądownictwa z dnia 27 października 1923 r. [w:] Komisja Kodyfikacyjna Rzeczypospolitej Polskiej. Podkomisja ustroju sądownictwa, t. II, Lwów 1925, s. 1-8; protokół posiedzenia Podkomisji ustroju sądownictwa z dnia 28 października 1923 r. [w:] ibidem, s. 8-15; protokół posiedzenia Podkomisji ustroju sądownictwa z dnia 29 października 1923 r. [w:] ibidem, s. 15-20; protokół posiedzenia Podkomisji ustroju sądownictwa z dnia 1 listopada 1923 r. [w:] ibidem, s. 49-53; protokół posiedzenia Podkomisji ustroju sądownictwa z dnia 29 listopada 1923 r. [w:] ibidem, s. 146-149; załącznik do protokołu posiedzenia Podkomisji ustroju sądownictwa z dnia 29 listopada $1923 \mathrm{r}$. [w:] ibidem, s. 149-150; protokół posiedzenia Podkomisji ustroju sądownictwa z dnia 30 listopada 1923 r. [w:] ibidem, s. 151-153.

${ }^{70}$ Komisja Kodyfikacyjna..., t. II, s. 158-165 (art. 16-56). Zob. zmiany w ustawie (projekcie) o sądach powszechnych (zamiast: zwyczajnych) projektowane przez pp. Mogilnickiego i Rappaporta oraz delegata Min. sprawiedl. p. Jamontta [w:] ibidem, s. 184-188; protokół posiedzenia Podkomisji przygotowawczej Komitetu Organizacji Prac Komisji Kodyfik. w sprawie projektu ustawy o sądach powszechnych z dnia 11 grudnia 1924 r. [w:] ibidem, s. 196-198.

${ }^{71}$ Komisja Kodyfikacyjna..., t. II, s. 253. 
projektu minister sprawiedliwości, w drodze rozporządzenia, miał określić, dla których gmin mają być ustanowieni sędziowie pokoju, w tym ich okręgi i siedziby, oraz stanowić o ich znoszeniu ${ }^{72}$.

Ponadto sędzia pokoju miał rozpoznawać spory między mieszkańcami swojego okręgu o roszczenia majątkowe, których wartość nie przekraczała sumy 30 zł, z wyjątkiem sporów: w których wartość przedmiotu nie wpływała na właściwość sądu; z weksli lub innych papierów wartościowych; o prawa do nieruchomości i prawa rzeczowe na nieruchomościach; w których pozwane było państwo lub inna instytucja prawa publicznego. Spory przed sędzią pokoju mogły być wytaczane przeciw pozwanym, zamieszkałym w okręgu sędziego pokoju, przez powodów niezamieszkałych w tym okręgu. Poza tym przed sędzią pokoju strony miały mieć możliwość zawarcia ugody we wszystkich sprawach majątkowych. Sędzia pokoju miał też rozpoznawać sprawy o przestępstwa, które należały do właściwości sądów grodzkich, jeśli ustawowy wymiar kary nie przekraczał 14 dni pozbawienia wolności lub 100 zł, w tym obu tych kar łącznie, niezależnie od kar dodatkowych. Jeżeli w danej miejscowości nie został ustanowiony sędzia pokoju, sprawy należące do jego właściwości miał rozpoznawać sędzia grodzki. W przypadkach wskazanych w ustawie sędzia pokoju miał wykonywać w sprawach niespornych poszczególne czynności oraz zlecenia sądu grodzkiego, do którego należał ${ }^{73}$.

W sądach ziemskich, zgodnie $\mathrm{z}$ art. 25 projektu, miały być utworzone w miejscowościach o większym ruchu handlowym zespoły składające się z sędziego handlowego i dwóch sędziów zawodowych, z których jeden był przewodniczącym ${ }^{74}$. Rozporządzenie ministra sprawiedliwości, wydane w porozumieniu z ministrem przemysłu i handlu, miało określić sądy ziemskie, w których miały być utworzone takie zespoły. Poza tym projekt regulował działalność sądów przysięgłych, które składały się z przewodniczącego i dwóch sędziów ziemskich oraz dwunastu przysięgłych. Przewodniczącego tego sądu miał wyznaczać sąd apelacyjny ze swojego grona lub spośród sędziów ziemskich. Właściwość sądów przysięgłych miała obejmować przestępstwa: zagrożone karą śmierci lub bezterminowym pozbawieniem wolności; za które najniższy ustawowy wymiar kary wynosił 10 lat pozbawienia wolności; które ustawa uznawała za polityczne. Działalność sądów przysięgłych mogła zostać zawieszona ze względów bezpieczeństwa publicznego

72 Ibidem, s. 257-261 (uzasadnienie).

${ }^{73}$ Art. 16-20 projektu ustawy o sądach powszechnych [w:] ibidem, s. 230-231, 273-275 (uzasadnienie).

${ }^{74}$ Właściwość tych zespołów określał art. 24 liczba 4-9 projektu. Były to sprawy z zakresu m.in. używania firmy handlowej, nabycia przedsiębiorstwa handlowego, z czynności giełdowych, ochrony patentów, znaków towarowych i wzorów, między członkami spółek handlowych, spółdzielni, prawa morskiego, żeglugi na wodach lądowych, ubezpieczeń, z wyjątkiem sporów o zapłatę premii. Zob. Komisja Kodyfikacyjna..., t. II, s. 275-280 (uzasadnienie). 
oraz przez wprowadzenie stanu wyjątkowego w siedzibie sądu ziemskiego lub wydziału zamiejscowego ${ }^{75}$.

Projekt normował także wybór sędziów pokoju, mianowanie sędziów handlowych oraz powołanie przysięgłych. Sędziego pokoju i jego zastępcę mieli wybierać mieszkańcy danego okręgu na 5 lat. Mógł nim być każdy, kto: mieszkał przynajmniej od roku w danym okręgu, korzystał z pełni praw cywilnych i obywatelskich, był nieskazitelnego charakteru, ukończył 30 lat, władał językiem polskim w mowie i piśmie oraz otrzymał wykształcenie w zakresie czterech klas państwowej szkoły średniej. Nie mógł zaś być sędzią pokoju: poseł do Sejmu lub senator, funkcjonariusz państwowy lub gminny w służbie czynnej, wojskowy w służbie czynnej, duchowny, adwokat, notariusz ani osoba, wobec której toczyło się postępowanie karne o przestępstwa z chęci zysku lub o zbrodnię. Czynne prawo wyborcze miał mieć każdy, kto w dniu ogłoszenia wyborów mieszkał w danym okręgu oraz posiadał czynne prawo wyborcze do Sejmu. Projekt regulował szczegółowo działalność komisji wyborczej i przebieg samych wyborów. Prawa i obowiązki sędziów pokoju, w tym ich odpowiedzialność dyscyplinarną, miało określić rozporządzenie ministra sprawiedliwości. Sędziowie pokoju mieli pełnić swoje obowiązki bezpłatnie, a koszty związane z ich wyborem oraz urzędowaniem miały ponosić właściwe gminy ${ }^{76}$.

Sędziów handlowych miał mianować minister sprawiedliwości na 3 lata, po zasięgnięciu opinii przedstawicielstwa stanu kupieckiego. Sędzią handlowym mogła być osoba, która: korzystała z pełni praw cywilnych i obywatelskich, była nieskazitelnego charakteru, ukończyła 30 lat, władała językiem polskim w mowie i piśmie oraz posiadała praktyczną znajomość obrotu handlowego i zwyczajów handlowych. Swoje obowiązki sędziowie handlowi mieli pełnić bezpłatnie. Minister sprawiedliwości miał określić w drodze rozporządzenia sposób powoływania sędziów handlowych, ich prawa i obowiązki, w tym odpowiedzialność dyscyplinarną ${ }^{77}$.

Obowiązki przysięgłego mogła wykonywać, podobnie jak w przypadku sędziego pokoju i sędziego handlowego, osoba, która: korzystała z pełni praw cywilnych i obywatelskich; była nieskazitelnego charakteru; 1 stycznia tego roku, w którym była układana lista pierwotna, ukończyła nie mniej niż 30 i nie więcej niż 65 lat; mieszkała w tym okresie przynajmniej od roku na obszarze danej gminy; władała językiem polskim; umiała czytać i pisać. Kobiety mogły być wciągnięte na listę przysięgłych na własne żądanie, zgłoszone przed dniem 15 sierpnia danego roku, skierowane do władzy, która układała listę pierwotną. Nie mogły być przysięgłymi osoby: przeciw którym toczyło się postępowanie karne o przestępstwo z chęci zysku lub o zbrodnię; które odbywały karę pozbawienia wolności lub były aresztowane na mocy postano-

\footnotetext{
${ }^{75}$ Art. 30-35 projektu [w:] ibidem, s. 232-233, 281-283 (uzasadnienie).

${ }^{76}$ Art. 79-97 [w:] ibidem, s. 238-240, 293-299 (uzasadnienie).

${ }^{77}$ Art. 98-102 [w:] ibidem, s. 241, 299-300 (uzasadnienie).
} 
wienia sądu; które z powodu wady umysłowej lub fizycznej nie mogły pełnić obowiązków przysięgłego; które otrzymywały stałe wsparcie z dobroczynności publicznej.

Ponadto nie mieli być powoływani na stanowisko przysięgłych: posłowie do Sejmu i senatorowie; funkcjonariusze państwowi w służbie czynnej; wojskowi w służbie czynnej; duchowni; lekarze w miejscowościach, w których mieszkało nie więcej niż dwóch lekarzy praktykujących; aptekarze, którzy nie mieli pomocników uprawnionych do wydawania lekarstw; sanitariusze w szpitalach. Listę pierwotną osób, które mogły być powołane do sprawowania obowiązków przysięgłego, układał w porządku alfabetycznym w sierpniu każdego roku urząd gminny i na dzień 1 października przesyłał ją prezesowi sądu ziemskiego. Listy roczne przysięgłych na okręg danego sądu ziemskiego miała układać komisja okręgowa, której przewodniczył prezes sądu ziemskiego. Komisja ta, na podstawie list pierwotnych, miała układać do 1 listopada każdego roku listy roczne główne oraz dodatkowe. Przysięgłego nie można było powoływać częściej niż raz w ciągu roku kalendarzowego. Pełnić oni mieli swoje obowiązki bezpłatnie, przy czym przysięgli zamiejscowi oraz utrzymujący się z zarobku dziennego otrzymywali diety według taksy określonej przez ministra sprawiedliwości ${ }^{78}$.

Prace Komisji Kodyfikacyjnej nad projektem prawa o ustroju sądów powszechnych trwały do końca grudnia $1924 \mathrm{r}{ }^{79}$, przy czym od 11 do 13 grudnia nad projektem obradowała komisja redakcyjna. W przypadku udziału czynnika obywatelskiego zajmowano się trzema zagadnieniami, tzn. kompetencjami sędziego pokoju, dopuszczeniem niższych urzędników do funkcji przysięgłych oraz unormowaniami dotyczącymi pełnienia przez przysięgłych swoich funkcji honorowo, przy czym zamiejscowi sędziowie przysięgli mieli otrzymywać diety. W dniach 14-15 grudnia miało miejsce posiedzenie Komitetu Organizacji Prac Komisji Kodyfikacyjnej, a przekazanie projektu wraz z motywami ministrowi sprawiedliwości nastąpiło 30 grudnia 1924 r. W ten sposób Komisja Kodyfikacyjna, po przekazaniu projektu ministrowi, nie miała już wpływu na jego dalsze losy. W 1925 r. projekt został przekazany sądom apelacyjnym do zaopiniowania. Następnie Ministerstwo Sprawiedliwości opracowało jego nową wersję, którą skierowano na posiedzenie Rady Ministrów. Projekt rządowy ustawy został przekazany Sejmowi, na podstawie uchwały Rady Ministrów z dnia 13 maja 1925 r., przez ministra sprawiedliwości. Składał się on z trzech załączników: projektu ustawy, uzasadnienia zmian dokonanych w projekcie Komisji Kodyfikacyjnej oraz projektu ustawy Komisji Kodyfikacyjnej $^{80}$. W lipcu 1926 r. projekt został wycofany przez rząd i ukazał się w postaci

${ }^{78}$ Art. 103-117 [w:] ibidem, s. 241-244, 300-302 (uzasadnienie).

79 Szerzej: B. Cybulski, Stosunek Komisji Kodyfikacyjnej RP..., s. 115 i n.; M. Materniak-Pawłowska, Ustrój sądownictwa powszechnego..., s. 176 i n.

${ }^{80}$ Projekt rządowy ustawy o sądach powszechnych, Sejm Rzeczypospolitej Polskiej, I kadencja (1922-1927), druk nr 1955. 
rozporządzenia Prezydenta Rzeczypospolitej Polskiej ${ }^{81}$. Warto zaznaczyć, że rozporządzenie Prawo o ustroju sądów powszechnych w sposób istotny odbiegało od projektu Komisji Kodyfikacyjnej. Jednakże zmiany dokonane przez Ministerstwo Sprawiedliwości w kwestii udziału czynnika obywatelskiego w orzecznictwie - jak stwierdził Bogdan Cybulski - „były wprawdzie istotne, ale zgodne z koncepcją wypracowaną przez KK" "82 (tj. przez Komisję Kodyfikacyjną).

\section{Czynnik spoleczny w rozporządzeniu Prezydenta Rzeczypospolitej z dnia 6 lutego 1928 r. Prawo o ustroju sądów powszechnych}

\subsection{Sędziowie pokoju}

Najniższym szczeblem sądownictwa powszechnego, zgodnie z rozporządzeniem Prezydenta Rzeczypospolitej z dnia 6 lutego 1928 r. Prawo o ustroju sądów powszechnych ${ }^{83}$, miały być sądy grodzkie wraz z podlegającymi im sędziami pokoju. Należy zaznaczyć, że sądy grodzkie zastąpiły sądy powiatowe oraz sądy pokoju. Na podstawie art. $2 \S 3$ rozporządzenia Prawo o ustroju sądów powszechnych minister sprawiedliwości w drodze rozporządzenia miał postanawiać: dla których gmin mieli być ustanowieni sędziowie pokoju, określać ich okręgi i siedziby, a także stanowić o ich znoszeniu ${ }^{84}$. W przypadku ustanowienia sędziego pokoju w okręgu sądu grodzkiego miało nastąpić zmniejszenie kompetencji sądu grodzkiego o sprawy temu pierwszemu przekazane. Sędziowie pokoju mieli rozpatrywać, zgodnie z art. 290 rozporządzenia, sprawy należące do właściwości sądów grodzkich, tj. spory między mieszkańcami swojego okręgu, w tym powództwa, mogły być wytaczane przez osoby niezamieszkałe $\mathrm{w}$ tym okręgu przeciwko pozwanym w nim zamieszkałym, o roszczenia majątkowe, jeśli wartość powództwa nie przekraczała 200 zł. Wyłączone były z atrybucji sędziów pokoju sprawy z zakresu sporów: w których wartość przedmiotu nie wpływała na właściwość sądu; z weksli, czeków, akcji, obligacji, listów zastawnych, dowodów składowych i innych papierów wartościowych; o prawa do nieruchomości i prawa rzeczowe na nieruchomościach; w których pozwany był Skarb Państwa lub inna osoba prawa publicznego. Ponadto przed sędzią pokoju strony mogły zawrzeć, ze skutkiem ugody sądowej, ugodę we wszel-

${ }^{81}$ Rozporządzenie Prezydenta Rzeczypospolitej z dnia 6 lutego 1928 r. Prawo o ustroju sądów powszechnych, Dz. U. Nr 12, poz. 93. S. Gołąb, Organizacja sądów powszechnych, s. 68 i n.; S. Włodyka, Organizacja wymiaru sprawiedliwości, s. 29-32; M. Materniak-Pawłowska, Ustrój sądownictwa powszechnego..., s. 183 i n.

${ }^{82}$ B. Cybulski, Stosunek Komisji Kodyfikacyjnej RP..., s. 118. Zob. A. Grzybowski, Uwagi o projekcie ustawy o sadach powszechnych, „Gazeta Sądowa Warszawska” 1927, nr 38.

${ }^{83}$ Art. 189-208 rozporządzenia Prezydenta Rzeczypospolitej Prawo o ustroju sądów powszechnych.

${ }^{84}$ Szerzej: S. Gołąb, I. Rosenblüth, Ustrój sądów powszechnych, s. 192 i n.; J. Maziarz, Sądy przysięgłych..., s. 91-94. 
kich sprawach majątkowych, jeśli wartość przedmiotu sporu nie przekraczała sumy 1000 zł, przy czym przedmiotem ugody nie mogły być prawa do nieruchomości ani prawa rzeczowe na nieruchomościach, $\mathrm{w}$ tym prawa i stosunki prawne, dla których powstania ustawa wymagała formy aktu notarialnego lub sądowego. Wynika z tego, że sędziowie pokoju mieli orzekać wyłącznie w sprawach cywilnych. Od orzeczeń sędziów pokoju, zgodnie z art. 293 rozporządzenia, miały przysługiwać te same środki odwoławcze co od orzeczeń sądów grodzkich, przy czym rozpatrywały je w drugiej i zarazem ostatniej instancji sądy grodzkie.

Sędziego pokoju i jego zastępcę mieli wybierać mieszkańcy danego okręgu na 5 lat. Prawo wyboru miały mieć osoby, które w dniu ogłoszenia wyborów mieszkały w danym okręgu oraz posiadały czynne prawo wyborcze do Sejmu. Sędzią pokoju mogła być, zgodnie z rozporządzeniem, osoba: posiadająca obywatelstwo polskie; korzystająca z pełni praw cywilnych i obywatelskich; zamieszkała przynajmniej od roku w danym okręgu; nieskazitelnego charakteru; władająca językiem polskim w mowie i piśmie oraz mająca ukończone 30 lat i sześć klas państwowej szkoły średniej. Nie mógł zaś być sędzią pokoju: poseł na Sejm lub senator; funkcjonariusz państwowy lub gminny w służbie czynnej; wojskowy w służbie czynnej; duchowny lub zakonnik; adwokat; notariusz; osoba, przeciwko której toczyło się postępowanie sądowe o przestępstwo z chęci zysku lub o zbrodnię.

W przypadku, gdy wybór nie został dokonany lub liczba oddanych głosów przy wyborze nie przekroczyła jednej trzeciej ogólnej liczby wyborców, sędziego pokoju oraz jego zastępcę miał mianować minister sprawiedliwości. Wybory miał zarządzać prezes sądu okręgowego, który: mianował przewodniczącego komisji wyborczej spośród sędziów sądu okręgowego lub grodzkiego; wzywał rady gminne do wyboru członków komisji wyborczej oraz zarządy gmin do sporządzenia spisów wyborców; ogłaszał w gminach okręgu wyborczego: dzień, godzinę i lokal wyborów, miejsce i czas do przeglądania listy wyborców oraz zgłaszania zarzutów, okres, w którym wyborcy mogli zgłaszać do komisji wyborczej kandydatów na sędziego pokoju i jego zastępcę, przy czym zgłoszenie takie powinno podpisać co najmniej dziesięciu wyborców. Ponadto Prawo o ustroju sądów powszechnych regulowało: wybór członków do komisji wyborczej, kwestię zgłaszania i rozpatrywania zarzutów zgłaszanych wobec osób znajdujących się na liście wyborców, sposób przeprowadzenia głosowania i wyboru na stanowisko sędziego i jego zastępcę, ustalenie wyniku głosowania, wnoszenie zarzutów do komisji wyborczej.

Prezes sądu okręgowego miał powoływać wybranych sędziów pokoju i ich zastępców. W przypadku wniesienia zarzutów lub jeśli sam powziął wątpliwości co do ważności wyborów, przekazywał akta sądowi okręgowemu, który mógł unieważnić wybory, gdy stwierdził, że zaszło uchybienie mogące mieć istotny wpływ na wynik wyborów bądź wybrano osobę niespełniającą warunków określonych w rozporządzeniu. Orzeczenia sądu okręgowego w przedmiocie ważności wyborów miały być 
ostateczne. W razie unieważnienia wyborów miały odbywać się ponowne wybory na sędziego i jego zastępcę, przy czym jeśli nowe wybory również zostały unieważnione, to sędziego pokoju i zastępcę miał mianować minister sprawiedliwości. Podobnie w przypadku nieprzyjęcia wyboru przez sędziego pokoju i jego zastępcę lub przedterminowego ich ustąpienia minister sprawiedliwości miał mianować sędziego pokoju i jego zastępcę do końca bieżącej kadencji.

Sędziowie pokoju i ich zastępcy mieli składać ślubowanie sędziowskie przed naczelnikiem sądu grodzkiego. Wykonywali oni swoje czynności aż do objęcia stanowiska przez ich następców, przy czym sędziego pokoju mógł zwolnić przed upływem kadencji minister sprawiedliwości na jego żądanie albo na podstawie uchwały zgromadzenia ogólnego sądu okręgowego. Prawa i obowiązki, w tym odpowiedzialność dyscyplinarną, sędziów pokoju miało określić rozporządzenie ministra sprawiedliwości. Co istotne, sędziowie pokoju mieli pełnić swoje obowiązki bezpłatnie, przy czym mogli, zgodnie z art. 208 rozporządzenia, „otrzymywać wynagrodzenie za oderwanie od zwykłych zajęć”. Koszty wyboru oraz urzędowania sędziów pokoju miały ponosić właściwe gminy. Szczegółowe kwestie miały być normowane przez rozporządzenie ministra sprawiedliwości wydane w porozumieniu z ministrem spraw wewnętrznych, a w przypadku wynagrodzenia sędziów - w porozumieniu z ministrem skarbu ${ }^{85}$.

Instytucja sędziów pokoju, przewidziana w Konstytucji z 1921 r. oraz w Prawie o ustroju sądów powszechnych z 1928 r., nigdy w praktyce nie funkcjonowała. Kolejna ustawa zasadnicza, tj. Konstytucja z 23 kwietnia 1935 r., w ogóle ją pominęła. Od samego wejścia w życie Prawa o ustroju sądów powszechnych instytucja sędziów pokoju budziła kontrowersje. Twierdzono m.in.: „Na szczęście niewiele zapewne znajdzie się osób z ukończoną 6 klasą gimnazjalną, któreby chciały prawieże za darmo, a sumiennie pełnić ten urząd dość absorbujący; w tem może nadzieja, że instytucja ta raczej pozostanie na papierze, niż wejdzie w życie" ${ }^{86}$. Ostatecznie minister sprawiedliwości nigdy nie skorzystał z uprawnienia zawartego w rozporządzeniu, które dawało możliwość powołania sędziów pokoju. Zwrócił na to uwagę w 1937 r. Wacław Miszewski, który stwierdził, że choć Prawo o ustroju sądów powszechnych obowiązuje od 1 stycznia 1929 r., czyli od 8 lat, to jak dotąd nie wydano żadnych rozporządzeń wykonawczych ani ustaw dodatkowych, „bez których wprowadzenie w życie przepisów o sędziach pokoju nie może nastąpić". Ponadto w żadnej miejscowości nie było dotąd sędziego pokoju, czyli „Inaczej

${ }^{85}$ Szerzej: A. Butterteig, Sędziowie pokoju, „Głos Adwokatów” 1928, z. 3; J. Bibring, Czynnik ludowy w nowym ustroju sądów powszechnych, „Głos Prawa” 1928, nr 7-8, s. 285-288; W. Miszewski, Sędzia pokoju, „Ruch Prawniczy, Ekonomiczny i Socjologiczny” 1937, z. 1; M. Materniak-Pawłowska, Ustrój sądownictwa powszechnego..., s. 206-210, 246-248.

${ }^{86}$ J. Bibring, Czynnik ludowy..., s. 288. 
mówiąc, przepisy te są martwą literą"87. W związku z tym ustawa z dnia 9 kwietnia 1938 r. o zniesieniu instytucji sądów przysięgłych i sędziów pokoju ${ }^{88}$ ostatecznie usunęła ich z ówczesnej „formalnej” struktury wymiaru sprawiedliwości.

\subsection{Sędziowie handlowi}

W rozporządzeniu Prezydenta Rzeczypospolitej Prawo o ustroju sądów powszechnych sędziowie handlowi stanowili osobny rodzaj udziału obywateli w wymiarze sprawiedliwości II Rzeczypospolitej. Sądy okręgowe, zgodnie z art. 21 rozporządzenia, którym podlegały miejscowości o znacznym ruchu handlowym, rozpoznawały w pierwszej instancji sprawy handlowe określone w ustawach. Wydział handlowy sądu okręgowego składał się z jednego sędziego okręgowego (zawodowego, który był przewodniczącym) oraz dwóch sędziów handlowych. Rozporządzenie ministra sprawiedliwości wydane w porozumieniu z ministrem przemysłu i handlu określało sądy okręgowe, w których były tworzone wydziały handlowe ${ }^{89}$.

Sędziowie handlowi byli mianowani na 3 lata przez ministra sprawiedliwości po wysłuchaniu opinii ministra przemysłu i handlu spośród osób zaproponowanych przez właściwe izby przemysłowo-handlowe ${ }^{90}$. Minister sprawiedliwości mógł zwolnić sędziów handlowych z tej funkcji przed upływem 3 lat na ich własne żądanie albo na podstawie orzeczenia zgromadzenia ogólnego sądu apelacyjnego. Sędzią handlowym mogła być osoba która: posiadała obywatelstwo polskie, korzystała z pełni praw cywilnych i obywatelskich, była nieskazitelnego charakteru, ukończyła 30 lat, władała językiem polskim w mowie i piśmie oraz posiadała praktyczną znajomość obrotu handlowego i zwyczajów handlowych. Sędziowie handlowi, przed objęciem swojej funkcji, składali ślubowanie sędziowskie przed prezesem sądu okręgowego. Co istotne, pełnili oni swoje obowiązki bezpłatnie ${ }^{91}$. Prawa i obowiązki, w tym odpowiedzialność dyscyplinarną, sędziów handlowych określało rozporządzenie ministra sprawiedliwości, przy czym tryb ich powoływania był określony w porozumieniu z ministrem przemysłu i handlu ${ }^{92}$.

${ }^{87}$ W. Miszewski, Sędzia pokoju, s. 204. Zob. S. Płaza, Historia prawa w Polsce..., s. 670.

${ }^{88}$ Dz. U. Nr 24, poz. 213.

${ }^{89}$ Rozporządzenie Ministra Sprawiedliwości w porozumieniu z Ministrem Przemysłu i Handlu z dnia 24 grudnia 1928 r. w sprawie utworzenia wydziałów handlowych w sądach okręgowych, Dz. U. Nr 104, poz. 947.

${ }^{90}$ Art. 4 pkt 9 rozporządzenia Prezydenta Rzeczypospolitej z dnia 15 lipca 1927 r. o izbach przemysłowo-handlowych, Dz. U. Nr 67, poz. 591, t.j. Dz. U. 1936, Nr 45, poz. 335. Szerzej: K. Dąbrowski, Samorząd gospodarczy. Izby przemystowo-handlowe [w:] R. Jastrzębski (red.), Prawo handlowe i gospodarcze..., s. $631 \mathrm{i} \mathrm{n.}$

${ }^{91}$ Art. 209-213 Prawa o ustroju sądów powszechnych.

${ }_{92}$ Rozporządzenie Ministra Sprawiedliwości z dnia 24 grudnia 1928 r. o prawach i obowiązkach oraz odpowiedzialności dyscyplinarnej sędziów handlowych, Dz. U. Nr 104, poz. 940; rozporządzenie Ministra Sprawiedliwości z dnia 24 grudnia 1928 r. wydane w porozumieniu z Ministrem 


\subsection{Sędziowie przysięgli}

Sąd okręgowy z udziałem przysięgłych, zgodnie z art. 24 rozporządzenia Prezydenta Rzeczypospolitej Prawo o ustroju sądów powszechnych, jako sąd przysięgłych miał się składać z trybunału oraz ławy przysięgłych. Trybunał mieli tworzyć przewodniczący i dwóch sędziów okręgowych, ławę przysięgłych zaś dwunastu przysięgłych. Rozporządzenie w kolejnych przepisach regulowało m.in. wyznaczanie przewodniczących i ich zastępców, określanie właściwości miejscowej sądów przysięgłych oraz zawieszanie ich działalności ${ }^{93}$.

Do sprawowania obowiązków przysięgłego, zgodnie z art. 214 rozporządzenia Prezydenta Rzeczypospolitej Prawo o ustroju sądów powszechnych, miały być powołane osoby płci męskiej, które: posiadały obywatelstwo polskie; korzystały z pełni praw cywilnych i obywatelskich; 1 stycznia roku, w którym były układane listy pierwotne, ukończyły co najmniej 30 i nie więcej niż 70 lat; 1 stycznia roku, w którym były układane listy pierwotne, mieszkały przynajmniej od dwóch lat na obszarze danej gminy; rozumiały po polsku; potrafiły czytać i pisać. Zgodnie z następnym przepisem rozporządzenia nie mogły być przysięgłymi osoby: które były skazane na karę pozbawienia wolności, nie wyłączając twierdzy za czyn przeciw państwu lub aresztu za czyn hańbiący, oraz osoby, przeciwko którym toczyło się postępowanie sądowe o przestępstwo, pociągające za sobą takie kary; które odbywały karę pozbawienia wolności lub były aresztowane na mocy postanowienia sądu; które z powodu wady umysłowej lub fizycznej nie mogły pełnić obowiązków przysięgłego; które utrzymywały się z dobroczynności publicznej; które czerpały zyski z nierządu.

Ponadto mieli nie być powoływani na sędziego przysięgłego: posłowie na Sejm i senatorowie; pozostający w czynnej służbie sędziowie, prokuratorzy, urzędnicy sekretariatu sądowego i urzędu prokuratorskiego, komornicy sądowi; funkcjonariusze policji państwowej w służbie czynnej; wojskowi w służbie czynnej; duchowni i zakonnicy; lekarze w miejscowościach, w których mieszkało nie więcej niż dwóch lekarzy praktykujących; aptekarze, którzy nie mieli pomocników uprawnionych do wydawania lekarstw; sanitariusze w szpitalach. W rozporządzeniu była przewidziana również możliwość zwolnienia od obowiązków przysięgłego, w razie zgłoszenia

Przemysłu i Handlu o trybie powoływania sędziów handlowych, Dz. U. Nr 104, poz. 939, zm. rozporządzenie Ministra Sprawiedliwości z dnia 7 lipca 1936 r. wydane w porozumieniu z Ministrem Przemysłu i Handlu w sprawie zmiany rozporządzenia z dnia 24 grudnia 1928 r. o trybie powoływania sędziów handlowych, Dz. U. Nr 52, poz. 382. Szerzej: J. Bibring, Czynnik ludowy..., s. 288-291; M. Allerhand, Sądownictwo handlowe, Warszawa 1929 (odbitka z „Przeglądu Prawa Handlowego” 1929, nr 4, 5-6); M. Materniak-Pawłowska, Ustrój sądownictwa powszechnego..., s. 210-212, 248-249; M. Materniak-Pawłowska, Sadownictwo w sprawach handlowych, s. 622 i n.

${ }_{93}$ Art. 25-30 rozporządzenia Prawo o ustroju sądów powszechnych. 
określonego żądania, osób, którym m.in. stan zdrowia nie pozwalał na pełnienie tych obowiązków; które ukończyły 65 lat; które w ubiegłym roku pełniły obowiązki przysięgłego; uznanych przez właściwego ministra za niezbędne w służbie publicznej.

Listę pierwotną osób, które mogły zostać powołane do sprawowania obowiązków przysięgłych, miał układać w sierpniu każdego roku zarząd gminny dla własnej gminy. Lista była ułożona w porządku alfabetycznym i obejmowała: imię i nazwisko, miejsce zamieszkania, wiek, zajęcie i stopień wykształcenia. Następnie, po wyłożeniu w zarządzie gminnym do przejrzenia, miała być ona przesyłana do powiatowej władzy administracji ogólnej, w której okręgu była położona gmina. Z kolei władza administracyjna miała przesyłać listę do prezesa sądu okręgowego. $\mathrm{Na}$ podstawie list pierwotnych komisja okręgowa, której przewodniczył prezes sądu okręgowego, układała listy roczne główne i dodatkowe. Na listy roczne miały być wciągane osoby z list pierwotnych charakteryzujące się nieskazitelnym charakterem, doświadczeniem życiowym, szczególnie uzdolnione do sprawowania obowiązków przysięgłych, a przede wszystkim osoby posiadające wykształcenie wyższe. Co najmniej na miesiąc przed rozpoczęciem każdego roku sądowego prezes sądu okręgowego, w obecności dwóch sędziów tego sądu, prokuratora, przedstawiciela izby adwokackiej oraz protokolanta, miał losować 30 przysięgłych z listy głównej i 15 z listy dodatkowej. Do pełnienia obowiązków przysięgłego nie można było powołać przysięgłego częściej niż na ,jedne roki” w ciągu roku kalendarzowego. Przysięgli mieli pełnić swoje obowiązki bezpłatnie, przy czym utrzymujący się z dziennego zarobku mieli otrzymywać odszkodowanie za utracony zarobek, a zamiejscowi przysięgli - diety i zwrot kosztów przejazdu. Na przysięgłego, który nie stawił się do sądu bez usprawiedliwienia, miała być nakładana przez sąd grzywna do $1000 \mathrm{z}^{194}$. Szczegółowe postępowanie przed sądem oraz tryb powołania ławy przysięgłych normowały przepisy Kodeksu postępowania karnego z dnia 19 marca 1928 r..$^{95}$

${ }^{94}$ Art. 214-230 rozporządzenia Prawo o ustroju sądów powszechnych. Szerzej: J. Bibring, Czynnik ludowy..., s. 283-285; S. Płaza, Historia prawa w Polsce..., s. 672; M. Materniak-Pawłowska, Ustrój sądownictwa powszechnego..., s. 213-214, 249-251.

${ }_{95}$ Art. 385-440 rozporządzenia Prezydenta Rzeczypospolitej z dnia 19 marca 1928 r. Kodeks postępowania karnego, Dz. U. Nr 33, poz. 313. Zob. Projekt ustawy postępowania karnego przyjęty przez Komisję Kodyfikacyjna Rzp. Pol. w dniu 28 kwietnia 1926, z uzasadnieniem [w:] Komisja Kodyfikacyjna Rzeczypospolitej Polskiej. Sekcja postępowania karnego, t. II, z. I, Lwów 1926, s. 506 i n.; Ustawy karne Rzeczypospolitej Polskiej, t. I: Kodeks postępowania karnego z ustawami dodatkowemi wydanemi do dnia 27 marca 1928 przypisami, skorowidzem i tablicami porównawczemi, oprac. A. Mogilnicki, E.S. Rappaport, cz. I: Teksty, Warszawa 1928, s. 92-104; Ustawy karne Rzeczypospolitej Polskiej, t. I: Kodeks postępowania karnego, cz. II: Motywy ustawodawcze, oprac. A. Mogilnicki, E.S. Rappaport, Warszawa 1929, s. 482-544; K. Sterling, Sądy przysiegtych podtug nowego Kodeksu Postępowania Karnego, „Gazeta Sądowa Warszawska” 1928, nr 38, 39, 40; A. Liebeskind, Sądy przysiegtych w Kodeksie polskiej procedury karnej, „Głos Prawa” 1928, nr 3-4; 
Sądy przysięgłych, zgodnie z art. 83 Konstytucji z dnia 17 marca 1921 r., miały orzekać o zbrodniach zagrożonych cięższymi karami i o przestępstwach politycznych. W praktyce sądy przysięgłych nie zostały powołane. Funkcjonowały tylko na obszarze byłej dzielnicy austriackiej według regulacji austriackich, na podstawie art. 274 rozporządzenia Prawo o ustroju sądów powszechnych. Zgodnie z tym przepisem do czasu jednolitego ustawowego określenia właściwości sądów przysięgłych i postępowania przed nimi pozostawały w mocy na poszczególnych obszarach prawnych dotychczasowe przepisy, o składzie sądzącym w sprawach należących do właściwości tych sądów lub izb karnych rozstrzygających w gronie dwóch sędziów zawodowych i pięciu niezawodowych, oraz o tworzeniu list przysięgłych i list sędziów niezawodowych. Konstytucja z 1935 r. w ogóle pominęła instytucję sędziów przysięgłych, a ostatecznie zniosła je ustawa z dnia 9 kwietnia 1938 r. o zniesieniu instytucji sądów przysięgłych i sędziów pokoju ${ }^{96}$.

\subsection{Sędziowie honorowi}

Ten rodzaj udziału przedstawicieli społeczeństwa w wymiarze sprawiedliwości, czyli sędziowie honorowi, został przewidziany w art. 276 przepisów przechodnich i końcowych rozporządzenia Prawo o ustroju sądów powszechnych i wprowadzony przez Ministerstwo Sprawiedliwości. Na podstawie tego przepisu minister sprawiedliwości, aż do odwołania w drodze rozporządzenia Prezydenta Rzeczypospolitej, mógł dla poszczególnych sądów okręgowych mianować honorowych sędziów okręgowych na 3 lata po zasięgnięciu opinii prezesa właściwego sądu apelacyjnego. Honorowi sędziowie okręgowi powinni byli: posiadać obywatelstwo polskie, korzystać z pełni praw cywilnych i obywatelskich, być nieskazitelnego charakteru, mieć ukończone 30 lat, władać językiem polskim w mowie i piśmie oraz posiadać wykształcenie wyższe. Taki sędzia miał wchodzić w skład sądzący sądu okręgowego zamiast sędziego grodzkiego, który rozpatrywał środki odwoławcze od orzeczeń sądów grodzkich, oraz zastępczo w skład sądzący sądu okręgowego ${ }^{97}$. Do sędziego honorowego okręgowego miały mieć zastosowanie odpowiednie przepisy dotyczące sędziów handlowych ${ }^{98}$. W praktyce jednak ten rodzaj udziału czynnika

\footnotetext{
W. Wolter, Kilka uwag o postępowaniu przed sądem przysięglych wedle kodeksu z 1928 r. (odbitka z „Czasopisma Prawniczego”), Kraków 1929; J. Hroboni, Instytucja sądów przysięgłych w nowym kodeksie post. kar., „Przegląd Prawa i Administracji” 1930, nr 1; A. Mogilnicki, Postepowanie przed sądem przysieglych wedtug k.p.k. i projektu, „Gazeta Sądowa Warszawska” 1930, nr 11, 12; idem, Kodeks postępowania karnego a projekt Komisji Kodyfikacyjnej, Warszawa 1931, s. 197 i n.; S. Glaser, Polski proces karny w zarysie wraz z prawem o ustroju sądów powszechnych, Kraków 1934, s. 345 i n.; J. Maziarz, Sady przysięglych..., s. 104 i n.

${ }^{96}$ Szerzej: J. Maziarz, Sady przysięgłych..., s. 133-155.

${ }^{97}$ Art. 20 i 23 § 2 rozporządzenia Prawo o ustroju sądów powszechnych.

98 Art. 209 § 2, art. 211-213 rozporządzenia Prawo o ustroju sądów powszechnych.
} 
społecznego w wymiarze sprawiedliwości nie funkcjonował, a art. $276 \mathrm{w}$ całości został skreślony przez ustawę z dnia 4 marca 1929 r. ${ }^{99}$

\section{Dyskusja i zniesienie czynnika społecznego w wymiarze sprawiedliwości II Rzeczypospolitej}

Od początku prac legislacyjnych nad udziałem czynnika społecznego w wymiarze sprawiedliwości zwracano uwagę na jego zakres. Dyskusja toczyła się w ramach prac Komisji Kodyfikacyjnej i ogniskowała się wokół instytucji sądów przysięgłych, którą przewidywał art. 83 Konstytucji z 17 marca 1921 r. W szczególności A. Mogilnicki, który początkowo był zwolennikiem sądów przysięgłych, zaproponował odejście od nich. Już bowiem w 1923 r. stwierdził:

Jako przejście od sądów państwowych zależnych, wyrokujących w myśl życzeń rządu, do sądu niezależnego, złożonego z obywateli, niepotrzebujących się liczyć z życzeniami władzy, sąd przysięgłych stanowi znaczny postęp w rozwoju sądownictwa. Osiąga jeden z najważniejszych postulatów dobrego sądu - niezależności od władzy wykonawczej. Ale w rzeczypospolitej demokratycznej, w państwie własnem, gdzie sędziowie państwowi korzystają z najdalej posuniętej niezależności, sąd przysięgłych nie jest już krokiem naprzód od sądów zależnych: niezależność przestaje być jego szczególnym przymiotem, sąd przysięgłych pozostaje przeżytkiem, wstecz; postępem zaś jest sąd państwowy, prawdziwie niezależny ${ }^{100}$.

Rozważano również zalety i ujemne strony sądu przysięgłych, porównując go przede wszystkim z sądem ławniczym, w tym zwracano uwagę na modele sądownictwa $\mathrm{w}$ innych państwach, zakres kognicji sądu przysięgłych oraz polskie unormowania konstytucyjne ${ }^{101}$. Zwolennicy sądów przysięgłych uważali, że „Siła

${ }^{99}$ Na podstawie art. 66 ustawy z dnia 4 marca 1929 r. w sprawie zmiany niektórych postanowień rozporządzenia Prezydenta Rzeczypospolitej z dnia 6 lutego 1928 r., zawierającego „Prawo o ustroju sądów powszechnych" (Dz. U. RP 1928, Nr 12, poz. 93), Dz. U. 1930, Nr 5, poz. 43. Zob. J. Bibring, Czynnik ludowy..., s. 291-292; M. Materniak-Pawłowska, Ustrój sądownictwa powszechnego..., s. 251-252.

100 A. Mogilnicki, Sądy przysięgtych w Polsce, s. 437. Zob. P. Stachańczyk, Sąd przysięglych..., s. 119-131; A. Grudzińska, Koncepcja systemu sądów przysięgłych do 1918 roku w myśli Aleksandra Mogilnickiego, „Annales Universitatis Mariae Curie-Skłodowska Lublin-Polonia” 2012, vol. LIX, 2, sectio G.

101 Szerzej: N. Oberlender, Sądy przysięgłych czy ławnicze?, „Głos Adwokatów” 1926, z. 7; T.W. Woner, W obronie sądów przysięgtych, „Gazeta Sądowa Warszawska” 1928, nr 51; T. Kraushar, Sady przysięgłych w Austrji, „Palestra” 1929, nr 2; A. Grzybowski, Sąd przysieglych a przestepstwa polityczne, „Głos Sądownictwa” 1929, nr 6; E.S. Rappaport, Zagadnienie sądu przysięgłych w Polsce (odpowiedź na ust. 4, Dz. XVII ankiety konstytucyjnej Sejmu R.P.), Warszawa 1931; A. Mogilnicki, Czy należy zachować sąd przysięgłych?, „Przegląd Sądowy” 1932, nr 2; E.S. Rappaport, Czy zalecić należy udziat czynnika społecznego w ustroju sadownictwa karnego państw stowiańskich?, Warszawa 1933; S. Wolski, Istota zagadnienia sądów...; E.S. Rappaport, Media via prawa karnego 
i powaga sądów przysięgłych polega na powołaniu do tego sądu głosu sumienia i rozumu narodu w osobach najlepszych jego przedstawicieli"' ${ }^{102}$. W związku z tym wprost stwierdzono:

Udział czynnika obywatelskiego we władzy i pożądanie takiego udziału przez szerokie warstwy ludności są czynnikami dodatniemi dla rozwoju społeczeństw [...]. Udział we władzy nadaje jednostkom i społeczeństwom wyrobienie, jakiego im dać nie mogłaby sama obserwacja i teoretyczne rozważania, a przez wciągnięcie czynnika obywatelskiego w czynny organizm władz państwowych zmienia się (z pożytkiem dla państwa) zasada i treść poglądów ludności na funkcjonowanie władz państwowych ${ }^{103}$.

Obrona sądów przysięgłych, które funkcjonowały na obszarze dawnej Małopolski, tj. dawnego zaboru austriackiego (Galicji), przed ich likwidacją, rozpoczęła się w 1937 r., czyli w trakcie prac nad projektem ustawy nowelizującej rozporządzenie Prezydenta Rzeczypospolitej Prawo o ustroju sądów powszechnych oraz postępowanie karne ${ }^{104}$. Projekt został wniesiony do Sejmu na podstawie uchwały Rady Ministrów z dnia 21 stycznia, pismem Ministra Sprawiedliwości z dnia 23 stycznia $1937 \mathrm{r}$. W uzasadnieniu do projektu stwierdzono:

Dawna konstytucja z 17 marca 1921 r. przewidywała dwa rodzaje sądów laickich, a mianowicie: a) sędziów pokoju, wybieralnych przez ludność (art. 76); b) sądy przysięgłych, powołane do orzekania o przestępstwach politycznych i o zbrodniach zagrożonych cięższymi karami (art. 83). [...] To stanowisko ustawy konstytucyjnej zmusiło prawodawcę polskiego do uwzględnienia $\mathrm{w}$ jednolitych ustawach procesowych i ustrojowych tych dwóch postaci sądu ludowego, aczkolwiek Komisja Kodyfikacyjna była zasadniczo przeciwna tym sądom i uważała je za nieprzydatne do wykonywania funkcyj wymiaru sprawiedliwości, [jednak] Względy praktyczne wraz z wątpliwościami zasadniczymi sprawiły, że pomimo istnienia odpowiednich przepisów - instytucje sędziów pokoju, sądów przysięgłych nie były nigdy wprowadzone w życie i pozostały martwą literą [a] Jedynie na obszarze apelacji lwowskiej i krakowskiej czynne były sądy przysięgłych, istniejące w spuściźnie po zaborcy.

polskiego. III. Kodeks karny polski a catoksztatt polskiego ustawodawstwa kryminalnego (postulaty reformy procesu karnego referat na III Zjazd Prawników Polskich), Warszawa 1936, s. 4-5; S. Płaza, Historia prawa w Polsce..., s. 666-669.

102 B. Wisznicki, Sądy przysięglych, „Palestra” 1927, nr 6, s. 245; J. Bross, Zagadnienia sądów przysięglych, „Głos Adwokatów” 1932, z. 3.

103 J.J. Bossowski, Czynnik ludowy..., s. 29.

104 Zob. Rządowy projekt ustawy o zmianach w ustroju sądów powszechnych i postępowaniu karnym, Sejm Rzeczypospolitej Polskiej. Kadencja IV, sesja zwyczajna r. 1936/37, druk nr 323; sprawozdanie stenograficzne z 36 posiedzenia Sejmu w dniu 9 lutego 1937 r., łam 5. 
Ponadto w uzasadnieniu do projektu zaznaczono:

Nowa ustawa konstytucyjna z 1935 r. odstąpiła od stanowiska konstytucji marcowej i uchyliwszy przepisy art. 76 i 83 konstytucji marcowej, przekazała całe zagadnienie organizacji sądów do swobodnego unormowania w drodze ustawy (art. 65 ust. 2), [a w] Obowiązującej obecnie ustawie konstytucyjnej nieznane są więc ani sądy przysięgłych, ani obieralni sędziowie pokoju. [...] Ten stan prawny zmusza prawodawcę do ostatecznego rozstrzygnięcia zagadnienia bytu sądów laickich, aby położyć kres rozbieżnościom, istniejącym dotąd między ustrojem sądów w b. dzielnicy austriackiej a pozostałymi sądami, oraz zharmonizować ustawy ustrojowe i procesowe z nową Konstytucją oraz ze stanem faktycznym ${ }^{105}$.

W dalszej części uzasadnienia likwidację „szczątków” sądownictwa przysięgłych w dawnym zaborze austriackim uzasadniano poglądami nauki i praktyki, zarzucano im zwłaszcza „niefachowość, uleganie nastrojom, nieposzanowanie prawa, nieobliczalność i dowolność w ferowaniu werdyktów". W związku z tym uznano, że „W naszych warunkach znane wady sądów przysięgłych uległyby pogłębieniu, na co wpłynąłby niewątpliwie brak rodzimej tradycji oraz mała kultura prawna szerokich rzesz społecznych". Co istotne, odrzucono również a limine wprowadzenie sądów ławniczych, gdyż próby ich wprowadzenia ,na obszarze b. zab. ros. w latach 1917-1921 dały wyniki bardzo ujemne. To też Komisja Kodyfikacyjna jednogłośnie niemal powzięła w 1920 r. uchwałę, że »udział czynnika ludowego w sądownictwie karnym w postaci sądów ławniczych jest niepożądany «"106. Na temat konieczności likwidacji sądów przysięgłych ukazywały się liczne publikacje na łamach prasy codziennej, które były związane z głośnymi procesami sądowymi, m.in. Rity Gorgonowej czy Adama Doboszyńskiego ${ }^{107}$.

Projekt ustawy został przekazany do Komisji Prawniczej ${ }^{108}$, a następnie 11 marca 1937 r. był przedmiotem burzliwych obrad sejmowych, przy czym został uchwalony przez Sejm oraz przyjęty bez zmian przez Senat ${ }^{109}$. Warto jednak zaznaczyć, że również w Senacie nie zabrakło wystąpień, które były za utrzymaniem sądów

${ }^{105}$ Uzasadnienie do rządowego projektu ustawy o zmianach w ustroju sądów powszechnych i postępowaniu karnym, Sejm Rzeczypospolitej Polskiej. Kadencja IV, sesja zwyczajna r. 1936/37, druk nr 323, s. 10-11.

${ }^{106}$ Ibidem, s. 11.

107 Zob. P. Stachańczyk, Spór o sądy przysięgłych w Polsce (1930-1938), „Zeszyty Naukowe Uniwersytetu Jagiellońskiego. Prace Prawnicze" 1992, t. MLII, z. 141.

108 Sprawozdanie Komisji Prawniczej, Sejm Rzeczypospolitej Polskiej. Kadencja IV, sesja zwyczajna r. 1936/37, druk Nr 406.

109 Sprawozdanie stenograficzne z 49 posiedzenia Sejmu w dniu 11 marca 1937 r. Sejm Rzeczypospolitej Polskiej. Kadencja IV, sesja zwyczajna r. 1936/37, łam 13-54; sprawozdanie stenograficzne z 52 posiedzenia Sejmu w dniu 23 marca 1937 r. Sejm Rzeczypospolitej Polskiej. Kadencja IV, sesja zwyczajna r. 1936/37, łam 3-4. 
przysięgłych ${ }^{110}$. Poza tym w izbie wyższej przegłosowano rezolucję, zgodnie z którą Senat wezwał rząd do przedstawienia izbom ustawodawczym projektu ustawy, powołującej do udziału w wymiarze sprawiedliwości czynnik społeczny, którego przedstawiciele mieli uczestniczyć razem z sędziami zawodowym w orzecznictwie karnym ${ }^{111}$.

Likwidacja sądów przysięgłych była też szeroko komentowana przez ówczesną prasę prawniczą i codzienną ${ }^{12}$. W „Kurierze Warszawskim” z 1937 r. wprost stwierdzono, że „Podłożem, z którego wynika walka przeciw sądom przysięgłych jest dążność do usunięcia pierwiastka samorządowego, do usunięcia wpływu społeczeństwa w sądownictwie"113. Znany ówczesny publicysta - Władysław Studnicki, zaznaczył na łamach wileńskiego „Słowa”:

Nie ma dziś żadnych przeszkód wprowadzenia sądów przysięgłych we wszystkich dzielnicach Polski. Idziemy na zrównanie in minus. Najbardziej politycznie rozwiniętą dzielnicę cofamy, pozbawiamy instytucji, do jakiej przywykła, z której była zadowolona, która funkcjonowała dobrze, aby ją upodobnić do innych dzielnic, które były politycznie bardziej upośledzone ${ }^{114}$.

Rezolucja Senatu spowodowała, że ówczesny rząd złożył w Sejmie projekt ustawy o udziale czynnika obywatelskiego w orzecznictwie karnym, który uchwaliła Rada Ministrów 1 czerwca 1938 r., a wniósł do Sejmu minister sprawiedliwości ${ }^{115}$. Projekt wprowadzał zmiany m.in. w rozporządzeniu Prezydenta Rzeczypospolitej Prawo o ustroju sądów powszechnych oraz Kodeksie postępowania karnego z 1928 r. Zgodnie z projektem sprawy o cięższe przestępstwa, określone w Ko-

110 Sprawozdanie stenograficzne z 48 posiedzenia Senatu w dniu 23 marca 1938 r., Senat Rzeczypospolitej Polskiej. Kadencja IV, sesja zwyczajna r. 1937/38, łam 42-77; sprawozdanie Komisji Prawniczej, Senat Rzeczypospolitej Polskiej. Kadencja IV, sesja zwyczajna r. 1937/38, druk nr 261.

${ }^{111}$ Ibidem, łam 77. Zob. T. Kosiński, Czynnik społeczny w sądownictwie karnym, „Głos Sądownictwa" 1938, nr 5; M. Rybicki, Lawnicy ludowi..., s. 82-92.

112 Szerzej: Dyskusja nad sądami przysięgtych, „Gazeta Sądowa Warszawska” 1937, nr 50, s. 707; W. Wolter, Proces przeciwko sądom przysięgłych, Kraków 1937 (odbitka z „Przeglądu Sądowego” nr 5); L. Sumorok, Sądy przysięgłych, „Głos Sądownictwa” 1937, nr 5; S. Różycki, Sądy przysięgłych: przeszłość a teraźniejszość, „Głos Sądownictwa” 1937, nr 5; S. Kijeński, W obronie sądów przysięgłych, „Odnowa” z 21 marca 1937 r. nr 17; L., Czy więc jednak nieuchronne zniesienie sądów przysięgłych! I dalejże odciążać sądy?..., „Głos Prawa” 1937, nr 10-12; Rok 1937, „Gazeta Sądowa Warszawska” 1938, nr 1; S. Glaser, Nieco prawdy o sądach przysięgłych, „Gazeta Sądowa Warszawska" 1938, nr 1.

113 S. Szurlej, Sądy przysięgłych, „Kurjer Warszawski” z 22 marca 1937 r. nr 81.

114 W. Studnicki, Wobec walki o sądy przysięgłych, „Słowo” z 22 marca 1937 r. nr 80.

115 Szerzej: Rządowy projekt ustawy o udziale czynnika obywatelskiego w orzecznictwie karnym, Sejm Rzeczypospolitej Polskiej. Kadencja IV, sesja nadzwyczajna VII. r. 1938, druk nr 839; Rządowy projekt ustawy o udziale czynnika obywatelskiego w orzecznictwie karnym, „Gazeta Sądowa Warszawska” 1938, nr 25, s. 396-400. 
deksie postępowania karnego, miał rozpoznawać sąd okręgowy w składzie trzech sędziów okręgowych, z których dwóch było sędziami obywatelskimi. Sędziów obywatelskich miał powoływać prezes właściwego sądu apelacyjnego na 3 lata spośród osób zaproponowanych przez sądowe komisje obywatelskie, które miały istnieć w okręgu każdego sądu okręgowego. W skład sądowej komisji obywatelskiej wchodzili: przedstawiciele samorządu terytorialnego; przedstawiciel właściwej izby adwokackiej, delegowany przez okręgową radę adwokacką; przedstawiciel właściwej izby notarialnej, delegowany przez radę notarialną; prezes sądu okręgowego (przewodniczący); prokurator sądu okręgowego; dwóch sędziów, wybranych przez zgromadzenie ogólne sądu okręgowego. Sądowa komisja obywatelska miała sporządzać listę trzech kandydatów na każde wolne stanowisko sędziego obywatelskiego.

Ponadto projekt określał przesłanki, jakie powinien spełniać kandydat na sędziego obywatelskiego, które dotyczyły m.in. posiadania obywatelstwa polskiego; korzystania z pełni praw cywilnych i obywatelskich; nieskazitelnego charakteru; ukończonych 30 lat; władania językiem polskim w mowie i piśmie. Stanowiska sędziego obywatelskiego nie mogli pełnić: posłowie na Sejm i senatorowie, duchowni i zakonnicy, funkcjonariusze państwowi i żołnierze w służbie czynnej. Sędziowie obywatelscy mieli pełnić swoje obowiązki bezpłatnie, przy czym mieli oni otrzymywać odszkodowanie za utracony zarobek, a zamieszkujący poza siedzibą sądu - diety i zwrot kosztów przejazdu. Wynika z tego, że projekt przypominał rozwiązania przejęte w rozporządzeniu Prawo o ustroju sądów powszechnych w zakresie sędziów przysięgłych. Zawierał także zmiany Kodeksu postępowania karnego z 1928 r., w tym katalog przestępstw, które miały być w kognicji sądu okręgowego rozpoznającego sprawy karne z udziałem sędziów obywatelskich. Należało do nich zaliczyć m.in. przestępstwa, za które ustawa przewidywała karę śmierci lub dożywotniego więzienia; przestępstwa, za które najniższy ustawowy wymiar kary wynosił 10 lat więzienia; wszystkie zbrodnie stanu. Wykonanie ustawy miało należeć do ministra sprawiedliwości.

W ten sposób zamiast zniesionych sądów przysięgłych na obszarze dawnego zaboru austriackiego miały być wprowadzone na całym obszarze ówczesnego państwa polskiego sądy ławnicze ${ }^{116}$. Jednak już 28 czerwca 1938 r. minister sprawiedliwości na posiedzeniu Komisji Prawniczej w imieniu Rady Ministrów wycofał rządowy projekt ustawy o udziale czynnika obywatelskiego w orzecznictwie karnym ${ }^{117}$.

116 Szerzej: S. Glaser, Kilka uwag o projekcie sądów tawniczych, „Gazeta Sądowa Warszawska" 1938, nr 35-36.

117 Zob. Sprawozdanie stenograficzne z 85 posiedzenia Sejmu w dniu 6 lipca 1938 r., Sejm Rzeczypospolitej Polskiej. Kadencja IV, sesja nadzwyczajna VII r. 1938, łam 5; sprawozdanie stenograficzne z 52 posiedzenia Senatu w dniu 14 lipca 1938 r., Senat Rzeczypospolitej Polskiej. Kadencja IV, sesja nadzwyczajna IV r. 1938, łam 3. 


\section{Czynnik społeczny w sądach szczególnych i odrębne instytucje quasi-sądowe}

W okresie II Rzeczypospolitej istniały także sądy szczególne, których organizację oraz działalność unormowano w odrębnych aktach prawnych. Nie były one zaliczane do sądów powszechnych, a co za tym idzie - ich funkcjonowania nie regulowało rozporządzenie Prezydenta Rzeczypospolitej Prawo o ustroju sądów powszechnych z 1928 r. ${ }^{118}$ Do sądów szczególnych zaliczano: sądy pracy, sądy przemysłowe, sądy kupieckie, sądy wojskowe, w których składzie występowali ławnicy ${ }^{119}$; sądy duchowne, które działały w b. zaborze rosyjskim w sprawach małżeńskich, w szczególności na podstawie prawa małżeńskiego z 1836 r. ${ }^{120}$

Sądy pracy zostały utworzone na podstawie rozporządzenia Prezydenta Rzeczypospolitej z dnia 22 marca 1928 r. o sądach pracy ${ }^{121}$. Do ich kognicji należało przede wszystkim rozstrzyganie spraw spornych cywilnych, wynikających ze stosunku pracy i nauki zawodu między pracodawcami a pracownikami lub uczniami. Sąd pracy składał się z przewodniczącego, zastępcy (zastępców) przewodniczącego oraz co najmniej 10 ławników i podwójnej liczby zastępców z każdej z dwóch grup, tj. pracodawców i pracowników. Ławników sądów pracy powoływał, w równej liczbie dla każdej z grup na okres dwuletni, minister sprawiedliwości na wspólny wniosek ministra pracy i opieki społecznej oraz ministra przemysłu i handlu, względnie ministra rolnictwa. Listy kandydatów przedstawiały m.in. izby przemysłowo-handlowe, izby rolnicze, stowarzyszenia zawodowe pracodawców oraz pracowników. Rozporządzenie określało przesłanki, jakie powinien spełniać kandydat na ławnika, które w zasadzie odpowiadały regulacjom Prawa o ustroju sądów powszechnych w stosunku do sędziów pokoju, sędziów handlowych czy sędziów przysięgłych ${ }^{122}$. Sąd pracy orzekał w składzie przewodniczącego lub jego zastępcy oraz jednego ławnika z grupy pracodawców i jednego z grupy pracowników. Generalnie od orzeczenia sądu pracy można było wnieść odwołanie do sądu okręgowego. Na podstawie

118 Szerzej: S. Gołąb, I. Rosenblüth, Ustrój sadów powszechnych, s. 209-210; S. Gołąb, Organizacja sąów powszechnych, s. 39-43; Ś. Kruszelnicki, Kodeks Postępowania Cywilnego, część I, art. 1-507 z komentarzem, Poznań 1938, s. 16-18; S. Włodyka, Organizacja wymiaru sprawiedliwości, s. 20-21; S. Płaza, Historia prawa w Polsce..., s. 698 i n.

119 Szerzej: T. Mallik, Wojskowe prawo karne i postępowanie karne [w:] F. Ryszka (red.), Historia państwa i prawa Polski 1918-1939, cz. II, s. 127-129; S. Płaza, Historia prawa w Polsce..., s. 694-695; J. Maziarz, Sady przysięgtych..., s. 93.

120 Szerzej: H. Konic, Dzieje prawa matzeńskiego w Królestwie Polskiem (1818-1836), Kraków 1903; K. Krasowski, Próby unifikacji osobowego prawa matżeńskiego w II Rzeczypospolitej, „Kwartalnik Prawa Prywatnego” 1994, z. 3; A. Fastyn, Jurysdykcja sadu konsystorskiego w świetle przepisów prawa matżeńskiego z 1836 r., „Czasopismo Prawno-Historyczne” 2010, t. LXII, z. 1; S. Płaza, Historia prawa w Polsce..., s. 695.

${ }_{121}$ Dz. U. Nr 37, poz. 350.

${ }^{122}$ Art. 12-18 ustawy. 
rozporządzenia Prezydenta Rzeczypospolitej z dnia 22 marca 1928 r. o sądach pracy sądy przemysłowe, działające na obszarze dawnego zaboru austriackiego, zostały przekształcone w sądy pracy. Kolejną regulacją normującą organizację i działalność sądów pracy było rozporządzenie Prezydenta Rzeczypospolitej z dnia 24 października 1934 r. Prawo o sądach pracy ${ }^{123}$. Uchyliło ono rozporządzenie z 1928 r., przy czym utrzymało skład ławniczy sądów pracy. Likwidacji uległy ponadto wymienione wyżej sądy przemysłowe i sądy kupieckie, działające w dawnym zaborze pruskim, które zasadniczo zajmowały się właśnie sprawami z zakresu prawa pracy ${ }^{124}$.

Osobną grupę stanowiły sądy szczególne, w których kognicji były sprawy z zakresu stosunków publicznoprawnych. Poza omówionymi wyżej trybunałami, tj. Trybunałem Stanu, Trybunałem Kompetencyjnym, NTA, należy do nich zaliczyć Sąd Kartelowy ${ }^{125}$ oraz Inwalidzki Sąd Administracyjny. Sąd Kartelowy, który funkcjonował przy Sądzie Najwyższym, miał charakter ławniczy. Orzekał w składzie pięcioosobowym, w którym było trzech sędziów Sądu Najwyższego delegowanych przez jego kolegium administracyjne (przewodniczący i dwóch członków) oraz dwóch członków, którzy byli wyznaczani z dwóch list osób (po jednym z każdej listy), posiadających szczególną znajomość stosunków gospodarczych i inne kwalifikacje wymagane od sędziów handlowych. Listy tych osób ustalał minister sprawiedliwości z właściwymi ministrami ${ }^{126}$.

Inwalidzki Sąd Administracyjny, funkcjonujący na podstawie ustawy z dnia 26 marca 1935 r. ${ }^{127}$, także miał charakter sądu ławniczego. Został utworzony przy NTA do orzekania o legalności orzeczeń wydanych w sprawach zaopatrzeń inwalidów wojennych i wojskowych oraz osób pozostałych po tych inwalidach, po poległych, zaginionych i zmarłych w związku ze służbą wojskową. Ławników powoływał na okres roku Prezes Rady Ministrów w dwóch grupach: grupie urzędników i grupie inwalidów. Ławnikiem z ostatniej grupy mógł być inwalida wojenny lub wojskowy, który był: obywatelem polskim, korzystał w pełni z praw cywilnych i obywatelskich, był nieskazitelnego charakteru, ukończył 30 lat, posiadał co najmniej średnie wykształcenie oraz władał językiem polskim w mowie i piśmie. Wyłączeni zaś byli: członkowie Sejmu i Senatu, posłowie Sejmu Śląskiego oraz funkcjonariusze państwowi i zawodowi wojskowi w służbie czynnej ${ }^{128}$.

${ }^{123}$ Dz. U. Nr 95, poz. 854.

124 S. Gołąb, Organizacja sądów powszechnych, Kraków 1938, s. 41-43; S. Płaza, Historia prawa $w$ Polsce..., s. 689-693.

125 Ustawa z dnia 28 marca 1933 r. o kartelach, Dz. U. Nr 31, poz. 270.

126 Szerzej: A. Podolska-Meducka, Polskie ustawodawstwo kartelowe w latach 1918-1939, Warszawa 2003, s. 173-218; eadem, Prawo kartelowe [w:] R. Jastrzębski (red.), Prawo handlowe i gospodarcze..., s. 370-379.

${ }_{127}$ Dz. U. Nr 26, poz. 177.

128 Art. 3-9 ustawy. Szerzej: D. Malec, Najwyższy Trybunat Administracyjny..., s. 100-103; M. Nowakowski, Okręgowe sądy ubezpieczeń społecznych, Kraków 2016, s. 33-36. 
Ponadto wyróżniano instytucje, które funkcjonowały na pograniczu państwowych sądów szczególnych oraz przymusowych sądów polubownych. Do tej kategorii zaliczano: komisje rozjemcze do załatwiania zatargów zbiorowych między pracodawcami a pracownikami rolnymi ${ }^{129}$; nadzwyczajne komisje rozjemcze do załatwiania zatargów zbiorowych między pracodawcami a pracownikami rolnymi ${ }^{130}$ oraz do załatwiania zatargów zbiorowych między właścicielami nieruchomości miejskich a dozorcami ${ }^{131}$; urzędy rozjemcze do spraw najmu ${ }^{132}$; sądy rozjemcze do spraw o wynagrodzenie szkód łowieckich ${ }^{133}$. Istniały także przymusowe sądy polubowne, do których zaliczano: giełdowe sądy rozjemcze ${ }^{134}$ oraz sądy rozjemcze dla Zakładu Ubezpieczeń od wypadków ${ }^{135}$.

W okresie wielkiego kryzysu gospodarczego lat 30. powstały urzędy rozjemcze, które stanowiły sui generis organy administracyjne o uprawnieniach z zakresu wymiaru sprawiedliwości. Zostały one powołane na podstawie rozporządzenia Prezydenta Rzeczypospolitej z dnia 23 sierpnia 1932 r. o utworzeniu urzędów rozjemczych do spraw kredytowych małej własności rolnej ${ }^{136}$, a ich działalność i organizację regulowała ustawa z dnia 28 marca 1933 r. o utworzeniu urzędów

${ }^{129}$ Ustawa z dnia 1 sierpnia 1919 r. o załatwianiu zatargów zbiorowych pomiędzy pracodawcami a pracownikami rolnymi, Dz. Praw Państwa Polskiego Nr 65, poz. 394; ustawa z dnia 23 września 1920 r. o rozszerzeniu działania przepisów ustawy z dnia 1 sierpnia 1919 r. o załatwianiu zatargów zbiorowych pomiędzy pracodawcami a pracownikami rolnymi (Dz. Praw $1919 \mathrm{Nr}$ 65, poz. 394) na zatargi zbiorowe między właścicielami nieruchomości miejskich a dozorcami domowymi, Dz. U. Nr 8, poz. 53.

${ }^{130}$ Ustawa z dnia 18 lipca 1924 r. w przedmiocie uprawnień Ministra Pracy i Opieki Społecznej do powoływania Nadzwyczajnych Komisji Rozjemczych do załatwiania zatargów zbiorowych pomiędzy pracodawcami a pracownikami rolnymi, Dz. U. Nr 71, poz. 686. Szerzej: A. Ajnenkiel, Polożenie prawne robotników rolnych $w$ Polsce (1918-1939), Warszawa 1962, s. 52-85, 162-176, 206-213, 265-284, 300-322, 374-409.

131 Ustawa z dnia 16 maja 1922 r. w przedmiocie powołania Nadzwyczajnej Komisji Rozjemczej do załatwiania zatargów zbiorowych pomiędzy właścicielami nieruchomości miejskich a dozorcami domowymi, Dz. U. Nr 39, poz. 324.

${ }^{132}$ Ustawa z dnia 11 kwietnia 1924 r. o ochronie lokatorów, Dz. U. Nr 39, poz. 406.

133 Rozporządzenie Prezydenta Rzeczypospolitej z dnia 3 grudnia 1927 r. o prawie łowieckiem, Dz. U. Nr 110, poz. 934.

${ }^{134}$ Rozporządzenie Prezydenta Rzeczypospolitej z dnia 28 grudnia 1924 r. o organizacji giełd, Dz. U. Nr 114, poz. 1019 (t.j. Dz. U. 1930, Nr 23, poz. 209). Szerzej: R. Jastrzębski, M. Dul, Prawne regulacje działalności giełd towarowych w Polsce, Warszawa 2007, s. 113-137.

${ }_{135}$ Rozporządzenie Ministra Pracy i Opieki Społecznej w porozumieniu z Ministrem Sprawiedliwości i Ministrem Przemysłu i Handlu z dnia 28 maja 1923 r. w przedmiocie siedziby oraz organizacji Sądów Rozjemczych dla Zakładu ubezpieczenia od wypadków we Lwowie, Dz. U. Nr 94, poz. 749; rozporządzenie Ministra Pracy i Opieki Społecznej z dnia 27 września 1927 r. w porozumieniu z Ministrem Sprawiedliwości o utworzeniu dla spraw Zakładu ubezpieczenia od wypadków sądów rozjemczych w Warszawie, Krakowie i Łodzi, Dz. U. Nr 87, poz. 782. Szerzej: S. Gołąb, I. Rosenblüth, Ustrój sądów powszechnych, s. 210-213.

${ }^{136}$ Dz. U. Nr 72, poz. 653. 
rozjemczych do spraw majątkowych posiadaczy gospodarstw wiejskich ${ }^{137}$ oraz rozporządzenie Prezydenta Rzeczypospolitej o konwersji i uporządkowaniu długów rolniczych ${ }^{138}$. Kognicja urzędów rozjemczych obejmowała długi rolnicze, a ich działalność miała na celu oddłużenie posiadaczy gospodarstw wiejskich m.in. poprzez rozłożenie tych długów na raty przy obniżonym oprocentowaniu oraz wstrzymanie egzekucji. W skład urzędów rozjemczych, które dzielono na wojewódzkie i powiatowe, wchodzili ławnicy powoływani i odwoływani odpowiednio przez prezesa sądu apelacyjnego w porozumieniu z wojewodą - wojewódzki urząd rozjemczy, albo przez prezesa sądu okręgowego - powiatowy urząd rozjemczy. Miały one jednocześnie charakter organów administracyjnych oraz sądów o charakterze polubownym ${ }^{139}$.

\section{WNIOSKI}

Udział czynnika społecznego był i jest zagadnieniem spornym w organizacji wymiaru sprawiedliwości. Dyskusja na ten temat była prowadzona po odzyskaniu przez państwo polskie niepodległości po I wojnie światowej oraz po 1945 r. Współcześnie także zgłaszane są postulaty włączenia czynnika społecznego do struktury wymiaru sprawiedliwości, zwłaszcza w postaci sędziów pokoju czy sędziów przysięgłych. Warto jednak zaznaczyć, że w okresie międzywojennym rzeczywiście funkcjonowały sądy, w których czynnik społeczny odgrywał istotną rolę. Były one niejako zakotwiczone w systemach państw zaborczych, a ich działalność została oparta w dużej mierze na XIX-wiecznych regulacjach.

Konstytucja z dnia 17 marca 1921 r. określała udział czynnika społecznego w wymiarze sprawiedliwości, w szczególności w postaci sędziów pokoju oraz sądów przysięgłych. Rozporządzenie Prezydenta Rzeczypospolitej Prawo o ustroju sądów powszechnych z 1928 r. normowało te instytucje oraz sędziów handlowych i honorowych sędziów okręgowych. W praktyce jednak funkcjonowali tylko sędziowie handlowi oraz sądy przysięgłych na obszarze dawnego zaboru austriackiego. W ostatnim przypadku ich organizację i działalność regulowały głównie unormowania austriackie.

W ten sposób po wejściu w życie rozporządzeń Prezydenta Rzeczypospolitej, tj. Prawa o ustroju sądów powszechnych z 1928 r. oraz Kodeksu postępowania karnego z dnia 19 marca 1928 r., działalność zarówno sądów przysięgłych, jak i sędziów pokoju na całym obszarze ówczesnego państwa polskiego była fikcją.

137 Dz. U. Nr 29, poz. 253.

${ }_{138}$ Dz. U. Nr 94, poz. 841 (t.j. Dz. U. 1936, Nr 5, poz. 59).

139 Szerzej: R. Jastrzębski, Wpływ siły nabywczej pieniadza na wykonanie zobowiązań prywatno-prawnych w II Rzeczypospolitej, Warszawa 2009, s. 354 i n. 
Dotyczyło to zwłaszcza sędziów pokoju, którzy według intencji Komisji Kodyfikacyjnej mieli być „ludźmi zaufania ludności”, a zakres ich kompetencji miał obejmować „sprawy, w których zaufanie ludności jest podstawą działalności sędziego”. Dlatego mieli oni ,spełniać zadania magistratur pojednawczych i zadania sądów, rozpoznających sprawy cywilne i karnego najmniejszego znaczenia społecznego i ekonomicznego" ${ }^{140}$. Niepowołanie sędziów pokoju, w tym sądów przysięgłych w sądach okręgowych, na podstawie dwóch wyżej wymienionych rozporządzeń, a następnie zniesienie tych ostatnich na obszarze dawnego zaboru austriackiego, zgodnie z ustawą z dnia 9 kwietnia w 1938 r., wynikało przede wszystkim z braku zaufania ówczesnych władz państwowych, zwłaszcza po 1926 r., do udziału czynnika społecznego (obywatelskiego) w wymiarze sprawiedliwości. Zresztą niejako zapowiedzią ich likwidacji były postanowienia Konstytucji z 23 kwietnia 1935 r., w której w ogóle nie było regulacji dotyczących udziału obywateli w sądownictwie powszechnym.

Warto jednak zaznaczyć, że sądy przysięgłych, działające tylko na obszarze dawnego zaboru austriackiego, nie miały dobrej prasy w zakresie jednostkowych rozstrzygnięć, m.in. w opinii Tadeusza Boya-Żeleńskiego przysięgli byli „dwunastoma ćwokami mającymi za cały pokarm 10-groszowe gazetki”, inni zaś uważali ich za „element ludzki przeważnie zacofany, konserwatywny, pełen uprzedzeń”. Ponadto ławy przysięgłych nie potrafiły „oderwać się od pewnych kastowych sympatii czy antypatii, czy nawet rasowych uprzedzeń" ${ }^{141}$. Pierwsze informacje o planie zniesienia sądów przysięgłych pojawiły się już w październiku 1936 r., czyli po wejściu w życie Konstytucji z 23 kwietnia 1935 r. Co istotne, w obronie tych sądów stanęła zarówno ówczesna prasa lewicowa, jak i prawicowa ${ }^{142}$. Likwidacja sądów przysięgłych w byłym zaborze austriackim zbiegła się ze sprawą Adama Doboszyńskiego - działacza endeckiego (przywódcy Stronnictwa Narodowego na powiat krakowski), który dokonał napadu zbrojnego na posterunek policji i starostwo w Myślenicach pod Krakowem. Sąd Okręgowy w Krakowie, a konkretnie ława przysięgłych, po 11 dniach procesu jednomyślnie go uniewinniła, podsądny zaś argumentował że ,wystąpienie jego było protestem przeciwko uprzywilejowaniu Żydów i bezkarnej działalności frontów ludowych”. Następnie trybunał uchylił werdykt, a Sąd Najwyższy przekazał sprawę do ponownego rozpoznania Sądowi Okręgowemu we Lwowie, również z udziałem przysięgłych. Przekazanie sprawy było związane z ówczesną atmosferą w Krakowie, tj. demonstracjami i rozruchami ulicznymi. W 1938 r. ława przysięgłych Sądu Okręgowego we Lwowie odpowiedziała przecząco na większość pytań, uznając jedynie, że miał miejsce

${ }^{140}$ Komisja Kodyfikacyjna Rzeczypospolitej Polskiej. Podkomisja ustroju sq̨downictwa, t. II, Lwów 1925, s. 258.

141 P. Stachańczyk, Spór o sądy przysięgłych..., s. 153-155.

142 Szerzej: ibidem, s. 161-162; J. Maziarz, Sądy przysięgtych..., s. 133-155. 
zabór i posiadanie broni. Trybunał zaś wymierzył A. Doboszyńskiemu karę dwóch lat $\operatorname{aresztu}^{143}$.

Oczywiście nadużyciem jest twierdzenie, jeszcze często powtarzane współcześnie, na co zwrócił uwagę niedawno Jakob Maziarz, a wcześniej w 1992 r. Piotr Stachańczyk, że sprawa A. Doboszyńskiego była bezpośrednim powodem likwidacji sądów przysięgłych ${ }^{144}$. Decyzja ta zapadła bowiem dużo wcześniej. Wypowiedział się na ten temat A. Mogilnicki, który stwierdził:

Zniesienie sądów przysięgłych nie było dla nikogo niespodzianką. Już w komisji kodyfikacyjnej przy opracowywaniu projektu k.p.k. znaczna większość jej członków, a zwłaszcza członków wydziału karnego wypowiedziała się przeciwko tej instytucji i tylko art. 83 konstytucji z r. 1921 zmusił Komisję Kodyfikacyjną do wprowadzenia sądów przysięgłych. [...] Z chwilą wprowadzenia w życie nowej konstytucji stało się rzeczą oczywistą, że dni sądów przysięgłych w Polsce są policzone ${ }^{145}$.

Zniesienie sądów przysięgłych w 1938 r. odbyło się iunctim ze zniesieniem instytucji sędziów pokoju, którzy po formalnym wejściu w życie rozporządzenia Prawo o ustroju sądów powszechnych w praktyce nie funkcjonowali. W ten sposób udział czynnika społecznego w wymiarze sprawiedliwości pod koniec II Rzeczypospolitej został ograniczony do udziału de facto ławników, w postaci sędziów handlowych funkcjonujących w wydziałach handlowych sądów okręgowych, które charakteryzowały się znaczniejszym ruchem handlowym, ławników sądów pracy oraz ławników albo członków innych sądów szczególnych, w tym odrębnych instytucji quasi-sądowych ${ }^{146}$.

W manifeście PKWN z 22 lipca 1944 r. ówczesne władze ludowe powoływały się na obowiązywanie podstawowych założeń Konstytucji z 17 marca $1921 \mathrm{r}$. W związku z tym został wydany dekret PKWN z dnia 15 sierpnia 1944 r. o wprowadzeniu Sądów Przysięgłych ${ }^{147}$, zgodnie z jego art. 1 została uchylona ustawa z dnia 9 kwietnia 1938 r. o zniesieniu instytucji sądów przysięgłych i sędziów

${ }_{143}$ P. Stachańczyk, Spór o sądy przysięgłych..., s. 166.

144 Szerzej: ibidem, s. 168-172.

145 A. Mogilnicki, Projekt ustawy ,o zmianach w ustroju sądów powszechnych i postępowaniu karnym”, „Gazeta Sądowa Warszawska” 1937, nr 7-8, s. 98.

146 Zob. A. Machnikowska, Wymiar sprawiedliwości w Polsce w latach 1944-1950, Gdańsk 2008, s. 226-228.

${ }^{147}$ Dz. U. Nr 2, poz. 7. Zob. F. Żukowski, Sąd przysięgtych - czy sądy ławnicze, „Wojskowy Przegląd Prawniczy" 1945, nr 2; W. Uruszczak, Niezależność sądów, niezawistość i samorząność sędziowska w dawnej i niedawnej Polsce [w:] P. Tuleja (red.), Krajowa Rada Sądownictwa. XX-lecie działalności, Warszawa 2010, s. 50 i n.; A. Machnikowska, Wymiar sprawiedliwości w Polsce..., s. 230-232; I.S. Grat, Dyskusje nad sadami ludowymi w pierwszych latach Polski Ludowej (na przykładzie sądów przysięgłych) [w:] J. Przygodzki, M.J. Ptak (red.), Społeczeństwo a władza. Ustrój, prawo, idee, Wrocław 2010. 
pokoju. Na podstawie kolejnego artykułu dekretu instytucja sądów przysięgłych miała funkcjonować na całym terenie Rzeczypospolitej Polskiej na zasadzie właściwych przepisów, które obowiązywały do dnia wejścia w życie ustawy wymienionej w poprzedzającym artykule dekretu. Następnie został wydany dekret PKWN z dnia 23 października 1944 r. o powołaniu i ukonstytuowaniu ławy przysięgłych ${ }^{148}$.

W praktyce jednak postanowienia obydwu dekretów obowiązywały „formalnie przez kilka lat na papierze", a ostatecznie zostały uchylone przez ustawę z dnia 27 kwietnia 1949 r. o zmianie prawa o ustroju sądów powszechnych ${ }^{149}$. Wynikało to z faktu, że nie zostały wydane regulacje wykonawcze do ostatniego z dekretów. Dlatego Sąd Najwyższy wydał postanowienie z dnia 2 października 1946 r., które dotyczyło kasacji wniesionej przez Prokuratora Sądu Najwyższego od wyroku Sądu Okręgowego w Przemyślu z 30 kwietnia 1945 r. W postanowieniu tym Sąd Najwyższy stwierdził expressis verbis:

Wobec niewydania dotychczas zarządzenia o rozpoczęciu działalności sądów przysięgłych, rozpoznawanie spraw przez sąd z udziałem ławy przysięgłych jest niedopuszczalne, a wyrok w tym trybie wydany jest z mocy prawa nieważny ${ }^{150}$.

Co istotne, ustawa z dnia 27 kwietnia 1949 r. o zmianie prawa o ustroju sądów powszechnych stanowiła, że w wypadkach wskazanych w ustawach sądy powszechne orzekają z udziałem ławników. Ławnicy w sprawowaniu swojego urzędu mieli być niezawiśli i podlegać tylko ustawom, a przy orzekaniu mieć prawa i obowiązki sędziów. Powoływał ich prezes sądu z listy, którą ustalało prezydium właściwej wojewódzkiej rady narodowej. W ten sposób zrezygnowano z sądów przysięgłych na początku kształtowania się ówczesnego państwa ludowego. Warto się jednak zastanowić, dlaczego to nastąpiło. Pod koniec lat 80 . XX w. uznano m.in.:

Ostra i bezwzględna walka prowadzona przez różne grupy i organizacje zbrojnego podziemia z organami władzy ludowo-demokratycznej doprowadziła do wydania nowych, znacznie surowszych ustaw karnych, mających zapewnić zwiększoną ochronę nowego ustroju i organów władzy ludowej. Doprowadziła ona więc do „zamrożenia” instytucji sądów przysięgłych jako nie odpowiadającej „potrzebie chwili”. [W związku z tym] w 1949 roku ostatecznie zrezygnowano z sądów przysięgłych i postanowiono zastąpić je sądami ławniczymi, zadecydował o tym przede wszystkim wzgląd na sytuację wewnętrzną kraju ${ }^{151}$.

148 Dz. U. Nr 9, poz. 47.

149 Dz. U. Nr 32, poz. 237. Zob. J. Potępa, Reforma postępowania karnego w sądach powszechnych (Zarys systemu), Łódź 1949, s. 10 i n.

150 Sygn. K. 1127/46, Zbiór Orzeczeń Sądu Najwyższego. Orzeczenia Izby Karnej, 1947, z. IV, poz. 95 , s. 177.

151 W. Hedrych, Sądy przysięgłych w II Rzeczypospolitej i w Polsce Ludowej, „Problemy Praworządności” 1988, nr 8-9, s. 65. 
Wpływ na to miała także praktyka funkcjonowania tego rodzaju sądów przed II wojną światową oraz rozwiązania przyjęte w Związku Socjalistycznych Republik Radzieckich, które wpływały na wymiar sprawiedliwości w innych państwach socjalistycznych, zwłaszcza ze względu na przyjęty w tym państwie model sądów ławniczych ${ }^{152}$. Warto zaznaczyć, że ławnicy byli wyjątkiem w sądownictwie II Rzeczypospolitej i funkcjonowali przede wszystkim w sądach rozpatrujących sprawy handlowe oraz ze stosunków pracy ${ }^{153}$.

Demokratyzacja sądownictwa, poza nieudaną próbą wprowadzenia sądów przysięgłych, miała również polegać na wprowadzeniu sądów obywatelskich, w których składzie zasiadali ławnicy wybierani przez rady narodowe. Sądy obywatelskie działały na podstawie dekretu z dnia 22 lutego 1946 r. Prawo o sądach obywatelskich $^{154}$. Kognicja tych sądów obejmowała sprawy karne i cywilne mniejszej wagi, które dotyczyły mieszkańców określonej gminy oraz przestępstw popełnionych na jej obszarze. Zakończenie działalności sądownictwa obywatelskiego nastąpiło w 1954 r. ${ }^{155}$

Wprowadzona instytucja ławników, początkowo w specjalnych sądach karnych oraz sądach wojskowych w 1944 r., a następnie w sądownictwie powszechnym stała się dominującą formą udziału czynnika społecznego w sądownictwie ówczesnego państwa polskiego po II wojnie światowej ${ }^{156}$. Poza tym ławnicy występowali m.in. w sądach pracy, sądach ubezpieczeń społecznych ${ }^{157}$, a czynnik obywatelski był także reprezentowany w pozasądowych instytucjach orzekających, takich jak: Komisja Specjalna do Walki z Nadużyciami i Szkodnictwem Gospodarczym, funkcjonująca w latach 1945-1954; w organach orzekających w sprawach lokalowych i podatkowych; w państwowym arbitrażu gospodarczym i zakładowych komisjach rozjemczych ${ }^{158}$.

Potwierdzeniem dominującej roli ławników, jako czynnika społecznego w ówczesnym wymiarze sprawiedliwości, były postanowienia Konstytucji Polskiej

${ }_{152}$ Szerzej: S.W. Bakszejew, Lawnicy ludowi w sądzie radzieckim, Warszawa 1953; Zagadnienia prawne Konstytucji Polskiej Rzeczypospolitej Ludowej. Materiały Sesji Naukowej PAN 4-9 lipca 1953 r., t. III, Warszawa 1954, s. 343-354; S. Włodyka, Organizacja sądownictwa, Kraków 1959, s. 74 i n.; M. Rybicki, Eawnicy ludowi..., s. 93 i n.

153 S. Włodyka, Organizacja sądownictwa, s. 73-74.

154 Dz. U. Nr 8, poz. 64.

155 Szerzej: Zagadnienia prawne Konstytucji Polskiej Rzeczypospolitej Ludowej..., t. III, s. 359-361; M. Rybicki, Ławnicy ludowi..., s. 142-151; A. Machnikowska, Wymiar sprawiedliwości w Polsce..., s. 242-248.

156 Szerzej: S. Włodyka, Organizacja sądownictwa, s. 189-206; M. Rybicki, Ławnicy ludowi..., s. 122 i n.; A. Machnikowska, Wymiar sprawiedliwości w Polsce..., s. 232-242.

157 M. Nowakowski, Okręgowe sady..., s. 133-146.

158 Szerzej: A. Lityński, Historia Prawa Polski Ludowej, Warszawa 2005, s. 29-41, 49-57; A. Machnikowska, Wymiar sprawiedliwości..., s. 414-423, 439-480. 
Rzeczypospolitej Ludowej z 22 lipca 1952 r. ${ }^{159}$ Zgodnie z jej treścią rozpoznawanie i rozstrzyganie spraw w sądach odbywało się z udziałem ławników ludowych, z wyjątkiem przypadków określonych w ustawie. Ławnicy ludowi byli wybierani, a tryb ich wyboru oraz kadencję - ławników sądów wojewódzkich i powiatowych określała ustawa ${ }^{160}$. Zasada udziału ławników ludowych w ówczesnym wymiarze sprawiedliwości miała stanowić demokratyzację wymiaru sprawiedliwości i gwarancję praworządności socjalistycznej ${ }^{161}$. W szczególności porównywano sądy z udziałem ławników z sądami przysięgłych. Twierdzono explicite:

Sądy przysięgłych, będące wyrazem światopoglądu burżuazyjnego nie mogą odpowiadać interesom państwa demokracji ludowej i dlatego nie zostały u nas przyjęte. Sądy przysięgłych nie gwarantowały pełni władzy mas ludowych w wymiarze sprawiedliwości. Gwarancję taką dają natomiast sądy z udziałem ławników ludowych ${ }^{162}$.

Zagadnienie udziału obywateli, tj. czynnika społecznego, czyli elementu niezawodowego w wymiarze sprawiedliwości, miało i ma miejsce przede wszystkim w okresie przemian polityczno-społecznych. Na kontynencie europejskim było to związane m.in. z Wielką Rewolucją Francuską (1789 r.) czy Wiosną Ludów (1848 r.), kiedy w poszczególnych państwach wprowadzano sądy z udziałem laików, takie jak: sądy pokoju, trybunały handlowe, sądy pracy, sądy przysięgłych ${ }^{163}$. Podobnie było w Polsce po I i II wojnie światowej, kiedy zaszły istotne zmiany polityczne. Co istotne, w II Rzeczypospolitej zakres udziału czynnika społecznego w dużej mierze był jeszcze oparty na wzorach i regulacjach państw zaborczych, a unormowania zawarte w Konstytucji z 17 marca 1921 r., w szczególności jej art. 83, nigdy nie zostały zrealizowane. Tak samo zresztą nie zostały w pełni wykonane postanowienia rozporządzeń Prezydenta Rzeczypospolitej z 1928 r., tj. Prawa o ustroju sądów powszechnych oraz Kodeksu postępowania karnego. Warto podkreślić, że realizacja zapowiadanych norm konstytucyjnych nie cieszyła się poparciem ówczesnych czynników władzy, zwłaszcza po 1926 r., czyli objęciu

159 Dz. U. Nr 33, poz. 232.

${ }^{160}$ Chodzi o art. 49-50 Konstytucji z 1952 r. Zob. Zagadnienia prawne Konstytucji Polskiej Rzeczypospolitej Ludowej..., t. III, s. 95, 108-109; Eawnicy ludowi w sqdach powszechnych. Ustawa o ławnikach ludowych i przepisy zwiazkowe, słowo wstepne Ministra Sprawiedliwości Mariana Rybickiego, Warszawa 1964; M. Rybicki, Ławnicy ludowi..., s. 217 i n.

161 Zagadnienia prawne Konstytucji Polskiej Rzeczypospolitej Ludowej..., t. III, s. 354-359; S. Włodyka, Organizacja sądownictwa, Kraków 1959, s. 64 i n.; S. Zawadzki, L. Kubicki (red.), Udziat ławników w postępowaniu karnym. Opinie a rzeczywistość. Studium prawnoempiryczne, Warszawa 1970; A. Turska, Czynnik społeczny i zawodowy w wymiarze sprawiedliwości, Warszawa 1971; F. Prusak, Czynnik społeczny w procesie karnym, Warszawa 1975, s. 11 i n.

162 Zagadnienia prawne Konstytucji Polskiej Rzeczypospolitej Ludowej..., t. III, s. 354.

163 B. Leśnodorski, Czynnik społeczny w sądach..., s. 497-504. 
władzy przez sanację. Następnie Konstytucja z 23 kwietnia 1935 r. w ogóle nie zawierała $\mathrm{w}$ swej treści postanowień dotyczących udziału czynnika społecznego w wymiarze sprawiedliwości. Ostatecznie ustawa z dnia 9 kwietnia 1938 r. zniosła, istniejące jeszcze na obszarze dawnego zaboru austriackiego, sądy przysięgłych oraz niefunkcjonującą w praktyce instytucję sędziów pokoju.

Problem zakresu udziału społeczeństwa w wymiarze sprawiedliwości pojawił się w państwie polskim także w latach 80 . XX w., czyli w okresie przemian polityczno-społecznych. Również współcześnie stanowi istotne zagadnienie ustrojowe, zwłaszcza w odniesieniu do składu sądów karnych. W tym przypadku sprowadza się zasadniczo do udziału w składzie orzekającym ławników albo wprowadzenia sądów przysięgłych ${ }^{164}$. Zresztą i obecnie obowiązujący lakoniczny art. 182 Konstytucji Rzeczypospolitej Polskiej z 2 kwietnia $1997 \mathrm{r}^{165}$, nie tak szczegółowy jak wspomniany wyżej przepis Konstytucji z 17 marca 1921 r., stanowi, że udział obywateli w sprawowaniu wymiaru sprawiedliwości określa ustawa. W ten sposób ustawodawca zwykły uzyskał niejako delegację konstytucyjną do wydania właściwych unormowań o charakterze ustawodawczym. Wynika z tego, jak stwierdził Stanisław Waltoś:

[...] ustawodawca ma pełną swobodę w decydowaniu, czy utrzymać instytucję ławników, czy ewentualnie zastąpić ją udziałem ławy przysięgłych, czy ewentualnie wprowadzić sądy obsadzane wyłącznie przez przedstawicieli społeczeństwa $[\ldots]^{166}$.

164 Szerzej: Z. Szcząska, Czynnik spoleczny w sądownictwie w II Rzeczypospolitej $i$ w Polsce Ludowej (część III), „Ławnik Ludowy” 1988, nr 2; A. Murzynowski, Udział ławników w orzecznictwie sądów karnych, „Zeszyty Naukowe. Instytut Badania Prawa Sądowego” 1985, nr 24; Lawnicy czy sady przysięgłych?, „Gazeta Prawnicza” z 16 lipca 1989 r., nr 14 (603); A.S. Bartnik, Sędzia czy kibic? Rola tawnika w wymiarze sprawiedliwości III RP. Analiza socjologiczno-prawna, Warszawa 2009; P. Karlik, Udziat czynnika społecznego w orzekaniu w sprawach karnych od czasów PRL [w:] M. Grochowski, J. Kostrubiec, E. Streit (red.), Wspótczesne przemiany państwa i prawa w krajach Europy środkowej i wschodniej, Lublin 2009; K. Wieczorek, Udziat czynnika spotecznego w orzekaniu $w$ polskim i amerykańskim procesie karnym, Szczecin 2012; C. Kulesza, Udziat czynnika społecznego w orzekaniu..., s. 61-63; J. Maziarz, Minione czasy sędziów przysięglych, „Rzeczpospolita" z 24 kwietnia 2018 r. nr 95 (11035).

165 Dz. U. Nr 78, poz. 483 ze zm. Zob. W. Skrzydło, S. Grabowska, R. Grabowski (red.), Konstytucja Rzeczypospolitej Polskiej. Komentarz encyklopedyczny, Warszawa 2009, s. 594-595; J. Sobczak, Sądy i trybunały [w:] W. Skrzydło (red.), Polskie prawo konstytucyjne, Lublin 2010, s. 393394; B. Banaszak, Konstytucja Rzeczypospolitej Polskiej. Komentarz, Warszawa 2012, s. 909-911; W. Skrzydło, Konstytucja Rzeczypospolitej Polskiej. Komentarz, Warszawa 2013, s. 241-243; B. Stępień-Załucka, Sprawowanie wymiaru sprawiedliwości przez Sąd Najwyższy w Polsce, Warszawa 2016, s. 198-203; M. Safjan, L. Bosek (red.), Konstytucja RP, t. II: Komentarz art. 87-243, Warszawa 2016, s. 1072-1076; L. Garlicki, Polskie prawo konstytucyjne. Zarys wykładu, Warszawa 2019, s. $390-391$.

166 S. Waltoś, Ławnik - czy piąte koło u wozu? [w:] T. Grzegorczyk (red.), Funkcje procesu karnego. Księga jubileuszowa Profesora Janusza Tylmana, Warszawa 2011, s. 524. 
Oczywiście zakres udziału czynnika społecznego w sądach może mieć charakter dwojaki, tj. sądy mogą mieć charakter niezawodowy i mieszany. W pierwszym przypadku czynnik społeczny (obywatelski) uczestniczy wyłącznie w wykonywaniu wymiaru sprawiedliwości. W praktyce zaś sprowadza się to do obsady sądów niższej instancji w sprawach zarówno cywilnych, jak i karnych. Drugi rodzaj, mieszany, był i jest związany z dopuszczeniem do udziału w składzie sądu przedstawicieli ludności w postaci specjalistów z określonej dziedziny, np. sędziów handlowych, oraz ławników. Osobnym zagadnieniem są sądy przysięgłych, których konstrukcja ustrojowa polega na tym, że ława przysięgłych orzeka w określonych sprawach karnych o winie podsądnego, wymiar kary należy zaś do sędziów zawodowych.

$\mathrm{Na}$ zakończenie warto zastanowić się nad stosunkiem władzy państwowej do udziału czynnika społecznego (obywatelskiego) w wymiarze sprawiedliwości, która bez względu na ustrój państwowy nie była ani nie jest obojętna na jego zakres. Egzemplifikacją tego jest właśnie państwo polskie zarówno w okresie międzywojennym, jak i po zakończeniu II wojny światowej. Cechą wspólną tych okresów było początkowe utrzymanie lub wprowadzenie regulacji prawnych gwarantujących formalne uczestnictwo obywateli w wymiarze sprawiedliwości - odnosi się to zwłaszcza do okresu II Rzeczypospolitej. Następnie odchodzono od tych rozwiązań na rzecz sądownictwa zawodowego albo marginalizacji roli czynnika społecznego w wymiarze sprawiedliwości. W związku z tym należy zgodzić się z S. Waltosiem, który uznał, że:

Autorytaryzm władzy bowiem nie toleruje pełnej niezawisłości sędziów i ławników lub przysięgłych. Wystarczą mu jej pozory. Jeżeli nie udaje się jej zawęzić pola niezawisłości sędziów, gdyż konstytucja lub inne akty prawne międzynarodowe na to nie pozwalają, zawsze pozostaje jeszcze możliwość pomniejszenia, a nawet zlikwidowania udziału przedstawicieli społeczeństwa w wymiarze sprawiedliwości ${ }^{167}$.

\section{THE CITIZEN FACTOR IN THE JUDICIARY \\ IN THE SECOND POLISH REPUBLIC}

\section{Abstract}

The article concerns the participation of the social (citizen) factor in the justice system (the judiciary) of the Second Polish Republic. The publication consists of four parts. The first part delineates the participation of the citizens in the judiciary from a historical perspective. The next part pertains to the contents of the basic laws of the Second Polish Republic, namely the Constitution of the Republic of Poland adopted on the $17^{\text {th }}$ of March 1921 and the April Constitution of Poland of the $23^{\text {rd }}$ of April 1935, due to their decisions concerning the citizens' participation in the justice system. The following part describes the

167 Ibidem, s. 526. 
implementation of the provisions of the March Constitution of 1921, i.e. the period prior to the unification of the judiciary system as well as the one after the regulation ("The law on system of common courts") of the President of the Republic of Poland of $6^{\text {th }}$ February 1928 came into force. The regulations which are discussed pertain to judges in particular: justices of the peace, commercial magistrates, jurors, honorary judges. Moreover, special attention was paid to the contemporary practice of the justice system, especially in connection with the abolition of jury trials on the territories of the former Austrian Partition (Galicia) in 1938 and the participation of the social factor in special courts as well as in quasi-court institutions. The last part of the paper contains a summing-up of the author's deliberations on the subject. Special attention was paid to the relationship between the state authorities and the citizen factor in the Polish judiciary in comparison with the period after the Second World War as well as with the modern solutions.

Keywords: citizen factor in judiciary, judiciary of Second Polish Republic, justices of peace, jurors, lay judges 